\title{
The historical role and contemporary use of corticosteroids in inflammatory bowel disease
}

Alexander M Dorrington ${ }^{1}$, Christian P Selinger ${ }^{2}$, Gareth C Parkes ${ }^{3}$, Melissa Smith ${ }^{4}$, Richard C Pollok ${ }^{5}$, Tim Raine ${ }^{1}$

${ }^{1}$ Cambridge University Hospitals Trust, Cambridge, UK

${ }^{2}$ Leeds Teaching Hospitals NHS Trust, Leeds, UK

${ }^{3}$ Royal London Hospital, Barts Health, London, UK

${ }^{4}$ Brighton and Sussex University Hospitals, Brighton, UK

${ }^{5}$ St George's University Hospitals NHS Trust, UK

Corresponding author:

Dr Tim Raine

Department of Medicine

Addenbrooke's Hospital

Cambridge CB2 0QQ

United Kingdom

Email: tim.raine@addenbrookes.nhs.uk

(C) The Author(s) 2020. Published by Oxford University Press on behalf of European Crohn's and Colitis Organisation. All rights reserved. For permissions, please email: journals.permissions@oup.com 


\section{ABSTRACT}

The use of corticosteroids to treat patients with inflammatory bowel disease (IBD) has been the bedrock of IBD therapeutics since the pioneering work of Truelove and Witts in the UK in the 1950s and subsequent large cohort studies in the US and Europe. Nevertheless, whilst effective for induction of remission, these agents do not maintain remission and are associated with a long list of recognised side effects, including a risk of increased mortality. With the arrival of an increasing number of therapies for patients with IBD, the question arises as to whether we are using these agents appropriately in contemporary practice. This review discusses the historical background to steroid usage in IBD, and also provides a brief review of the literature on side effects of corticosteroid treatment as relevant to IBD patients. Data on licensed medications is presented with specific reference to the achievement of corticosteroid-free remission. We review available international data on the incidence of corticosteroid exposure and excess and discuss some of the observations we and others have made concerning healthcare and patient-level factors associated with the risk of corticosteroid exposure, including identification of 'at-risk' populations. 


\section{INTRODUCTION}

For over 70 years, corticosteroids have been a cornerstone therapy in the management of inflammatory bowel disease (IBD). Nevertheless, whilst effective for induction of remission, these agents do not maintain remission and are associated with a plethora of recognised adverse effects, including a risk of increased mortality. With the arrival of an increasing number of therapies for patients with IBD, the question arises as to whether these agents are being used appropriately in contemporary practice and what practical strategies can minimise inappropriate use of these agents. 


\section{Box text number 1: MECHANISM OF ACTION OF CORTICOSTEROIDS IN IBD}

Administered exogenous corticosteroids bind to the glucocorticoid receptor (GR), which is resident in the cytoplasm of all human cells. The activated GR complex can then migrate into the nucleus, where it regulates gene expression via direct binding of glucocorticoid responsive elements on DNA or by tethering itself to other transcription factors. ${ }^{1}$ In studies using triggered human mononuclear cells, corticosteroids powerfully reduce the production of the initial phase cytokines IL-1 beta and TNF-alpha, as well as of IL-6, IL-8 and GM-CSF. Synthesis of immunomodulatory cytokines such IL-2, IL-3, IL-4, IL-5, IL-10, IL-12 and IFN-gamma is similarly reduced. ${ }^{2}$ As a result, corticosteroids can exert a strong immunosuppressive effect, but this can come the cost of undesirable and sometimes severe adverse effects, the range of which reflect the wide expression pattern of the GR and the large number of GR target sites in the genome.

\section{Box text number 2: PHARMACOLOGICAL DIFFERENCES BETWEEN FIRST-GENERATION CORTICOSTEROIDS}

Given the heterogeneity in agents used in different IBD trials, a basic understanding of the different characteristics of commonly used systemic corticosteroids is important when reviewing the literature in this area. Table 1 summarises the key differences between available systemic corticosteroids. Hydrocortisone is a short-acting systemic corticosteroid with relatively high mineralocorticoid activity. In contrast, prednisone, prednisolone, and methylprednisolone are all intermediate-acting systemic corticosteroids that exert a stronger glucocorticoid effect in conjunction with diminished mineralocorticoid activity. ${ }^{3}$ Prednisone is a prodrug, which is converted to the active drug prednisolone in the liver. Therefore, both drugs are considered equivalent in terms of dose, glucocorticoid, and mineralocorticoid activity. ${ }^{4}$ Methylprednisolone has a slightly more potent glucocorticoid activity $(4 \mathrm{mg}$ is considered equivalent to $5 \mathrm{mg}$ of prednisone/prednisolone) and negligible mineralocorticoid activity. ${ }^{3}$ 


\section{INDUCTION OF REMISSION}

After decades of poor outcomes and high mortality rates, the utility of corticosteroids in the treatment of IBD was first established in the 1950s. Several observational reports published between 1950 and 1952 noted a subjective improvement in appetite and diarrhoea seen in ulcerative colitis (UC) patients who were given cortisone or ACTH. ${ }^{5-12}$ A breakthrough study in 1955 by Truelove and Witts published the findings of a multicentre randomised double-blind placebo-controlled trial examining $100 \mathrm{mg}$ cortisone per day in a cohort of 210 patients with UC. After six weeks, $41 \cdot 3 \%$ of patients treated with $25 \mathrm{mg}$ cortisone four times per day were in remission, in comparison to $15.8 \%$ in the placebo arm $(p<0.001) .{ }^{13}$ In addition to the clinical outcomes, sigmoidoscopy carried out at the conclusion of the induction period was more likely to be normal in the cortisone treatment group ( $p=0.02$ ). ${ }^{13}$ Two subsequent controlled trials in the early 1960 s found corticosteroids to be superior to sulphasalazine for inducing clinical remission in active UC. ${ }^{14,15}$ A 2011 meta-analysis of five randomised controlled trials concluded that corticosteroids are more effective than placebo for inducing remission in active UC (RR of no remission 0.65; 95\% $\mathrm{Cl} 0 \cdot 45-0 \cdot 93$ ). ${ }^{16}$

Truelove and colleagues also established the efficacy of systemic corticosteroids in acute severe UC in the 1970's. In their landmark study, 87 patients received a complicated regimen of intravenous (IV) methylprednisolone $60 \mathrm{mg}$ per day in four divided doses, in conjunction with a twice daily $100 \mathrm{mg}$ hydrocortisone rectal drip in $120 \mathrm{ml}$ normal saline for a total of five days. By day five, $60 \%$ of patients were free of symptoms, $15 \%$ had achieved a partial clinical response and 25\% required colectomy. ${ }^{17,18}$ A 1985 uncontrolled Swedish study using IV betamethasone in place of methylprednisolone produced similar results, with $56 \%$ of the 158 patients achieving clinical remission by day five. This group also showed that disease refractory to oral prednisolone could be treated intravenously. ${ }^{19}$ However, there does not appear to be any benefit in extending intravenous corticosteroid beyond seven to ten days in acute severe colitis. ${ }^{20}$ A 2007 systematic review of 32 trials in acute severe colitis 
reported an overall response rate to IV corticosteroids of $67 \% .^{21}$ In acute severe colitis, IV methylprednisolone may be preferred over hydrocortisone, as it has less mineralocorticoid activity, resulting in less hypokalaemia 22

High quality evidence supporting the use of corticosteroids in Crohn's disease (CD) did not arrive for another two decades. In 1979, the National Cooperative Crohn's Disease Study (NCCDS) published multicentre randomised controlled trial data from the United States demonstrating the superiority of prednisone $(60 \%)$ over placebo (30\%) in the induction of clinical remission in 295 patients with active CD. ${ }^{23}$ Moreover, the 1984 European Cooperative Crohn's Disease Study (ECCDS) clearly demonstrated the superiority of methylprednisolone over placebo for achieving clinical remission at week six in a cohort of 215 patients with active CD. ${ }^{24} \mathrm{~A} 2008$ Cochrane review including two placebo controlled trials and six 5-aminosalicylate (5-ASA) controlled trials confirmed the superiority of corticosteroids in achieving clinical remission over placebo (RR 1.99; $95 \% \mathrm{Cl} 1.51-2.64 ; p<0.00001$ ) and 5-ASA (RR 1.65; 95\% Cl 1.33-2.03; $p<0.00001)$ in CD. ${ }^{25}$

Although systemic corticosteroid treatment improved short-term outcomes in UC and CD, side effects were becoming an increasingly recognised issue in clinical practice and the literature. Hence, the arrival of budesonide in 1994 as a treatment option in CD was timely. However, the unique pharmacokinetic properties of budesonide have restricted its use to patients with ileocolonic and right-sided colonic CD. ${ }^{26-28} \mathrm{~A}$ randomised controlled trial conducted in 186 patients with active ileal or ileocaecal CD found that $53 \%$ of patients treated with budesonide achieved clinical remission at week ten in comparison to $66 \%$ of patients who received prednisolone $(p=0 \cdot 12)$. Prednisolone therapy did, however, achieve a greater reduction in disease activity than budesonide. Importantly, corticosteroid related side effects were less common in the budesonide group $(p=0.003) .{ }^{29}$ Several subsequent controlled studies confirmed the effectiveness of budesonide in achieving remission in active $C D$, with clinical remission rates at 8-12 weeks varying between 51 to $69 \% .{ }^{30-34}$ A 2015 Cochrane systematic review found that budesonide was superior to placebo in achieving remission in active $C D$, but was not as effective as conventional corticosteroids in the short term, particularly in those with severe disease and more extensive colonic involvement. ${ }^{35}$

In the last two decades, second-generation corticosteroid preparations have also emerged for use in the management of UC. Two randomised placebo-controlled studies and a systematic review of ileal release budesonide have shown that it does not induce clinical remission in mild-moderate UC. ${ }^{36-38}$ Budesonide MMX adopts a multi-matrix system that enables a targeted release of steroid within the colon. ${ }^{39}$ The CORE I and CORE II studies were randomised controlled trials comparing budesonide MMX $6 \mathrm{mg} /$ day or $9 \mathrm{mg} /$ day with placebo and Asacol $2.4 \mathrm{~g} /$ day (CORE I) or ileal release budesonide $9 \mathrm{mg} /$ day (CORE II) in mild-to-moderate UC. ${ }^{40,41} \mathrm{~A}$ pooled analysis of both trials showed a combined clinical and endoscopic remission rate of $17 \cdot 7 \%$ for budesonide MMX $9 \mathrm{mg} /$ day versus $6 \cdot 2 \%$ for placebo $(p=0 \cdot 0002)$. The $6 \mathrm{mg} /$ day dose was not superior to placebo. These studies were not 
powered to find differences between budesonide $M M X$ and the active treatment arms. ${ }^{42}$ Subgroup analysis in CORE I and CORE II found that clinical and endoscopic remission was significantly better with budesonide MMX than placebo in left-sided disease, but not extensive disease. ${ }^{40,41}$ The lack of treatment benefit in extensive UC was confirmed in a subsequent Cochrane systematic review. ${ }^{38} \mathrm{~A}$ subsequent randomised controlled trial comparing budesonide MMX $9 \mathrm{mg} /$ day with placebo in 510 mild to moderate UC patients who were flaring on 5-ASA therapy, demonstrated a significant improvement in combined clinical and endoscopic remission (13\% vs. $7 \cdot 5 \%, p=0.0488)$ and histological healing in the treatment arm (27\% vs. $17 \cdot 5 \%, p=0 \cdot 0155) .^{43}$

Beclomethasone dipropionate (BDP) is another second-generation corticosteroid that has evidence supporting its utility in UC. In a 2003 randomised controlled trial, BDP was shown to be as effective as 2.4 $\mathrm{g}$ 5-ASA in reducing the combined clinical and endoscopic disease activity index score in 177 patients with active left-sided or extensive UC. ${ }^{44}$ In addition, the combination of BDP with 5-ASA was shown to be superior to 5-ASA alone in a similar patient cohort. ${ }^{45} \mathrm{~A}$ randomised double-blind study of 282 mild-to-moderate UC patients demonstrated that $5 \mathrm{mg}$ BDP once daily was not inferior to tapered prednisone (starting at a dose of $40 \mathrm{mg}$ once daily) in achieving the clinical response at week four $(64 \cdot 6 \%$ for BDP vs. $66 \cdot 2 \%$ for prednisone [delta: $-1 \cdot 56 ; 95 \% \mathrm{Cl}-13 \cdot 00-9 \cdot 88, \mathrm{p}=0.78]) .{ }^{46} \mathrm{~A}$ subsequent systematic review of five controlled trials concluded that beclomethasone was superior to 5-ASA for achieving clinical improvement in mild-moderate UC $(p=0.003)$, with a trend toward a higher rate of clinical remission $(p=0 \cdot 05) .{ }^{47}$ 


\section{MAINTENANCE OF REMISSION}

Although there is plentiful evidence demonstrating the efficacy of corticosteroids for inducing remission in $I B D$, data relating to the maintenance of remission is disappointing. In the landmark NCCDS study, among the 274 CD patients in clinical remission, prednisolone at doses of up to $20 \mathrm{mg}$ per day did not reduce flares or disease recurrence after surgery. ${ }^{23}$ A 2003 Cochrane systematic review found that conventional oral corticosteroids do not reduce the risk of CD relapse over a 24month follow-up period. ${ }^{48}$

A 2014 Cochrane systematic review that incorporated 1273 participants from 12 studies concluded that budesonide use beyond three months is ineffective at maintaining remission in $\mathrm{CD}^{49} \mathrm{~A}$ subsequent systematic review and meta-analysis in 2018 also found that budesonide was no better than placebo in maintaining remission in $\mathrm{CD} .{ }^{50}$

The effectiveness of corticosteroids in achieving endoscopic mucosal healing and preventing endoscopic relapse in CD is also limited. In a French study of 136 CD patients who had achieved clinical remission after oral prednisolone $1 \mathrm{mg} / \mathrm{kg} /$ day for a duration of 3-7 weeks, $71 \%$ still had active endoscopic lesions. Only $13 \%$ of patients who were in clinical remission from corticosteroids had mucosal healing at endoscopy. ${ }^{51}$ Another study in $130 \mathrm{CD}$ patients post-ileocaecal resection treated with either maintenance budesonide $6 \mathrm{mg} /$ day or placebo found no difference in endoscopic recurrence in the neo-terminal ileum at 12 months ( $52 \%$ vs. $58 \%$ respectively). ${ }^{52}$

Systemic corticosteroids are not effective for maintaining remission in UC. Truelove and Witts found that oral cortisone $50 \mathrm{mg} /$ day was ineffective at maintaining remission in $68 \mathrm{UC}$ patients who had initially achieved corticosteroid-induced clinical remission. ${ }^{53}$ Prednisone $15 \mathrm{mg} /$ day $(5 \mathrm{mg}$ three times daily) was no different to placebo with regards to UC clinical relapse and remission after six months. ${ }^{54}$ With respect to mucosal healing in UC, an uncontrolled trial involving 157 patients treated with a 3 month tapered course of systemic corticosteroids within a year of initial diagnosis reported that $61.8 \%$ had persistent endoscopic activity at 3 months. ${ }^{55}$ 


\section{SAFETY OF FIRST-GENERATION CORTICOSTEROID THERAPY}

Whilst corticosteroids have revolutionised the treatment of IBD since the mid-twentieth century, the widespread use of these agents has come at the cost of a myriad of adverse effects (AEs) for patients. Table 2 lists each of the AEs of corticosteroids with corresponding frequency based on published literature. It is worth noting that despite decades of use, there are still significant knowledge gaps in terms of the exact incidence of some AEs, particularly with regard to some of the less serious AEs that might nonetheless be of particular importance for patients. The frequency and severity of the overwhelming majority of AEs is dependent on the dose and duration of corticosteroids. ${ }^{56}$ In general, AEs are more likely to occur when corticosteroids are used daily for a period beyond two to three weeks. ${ }^{56}$ Approximately $50 \%$ of patients will develop short-term corticosteroid related AEs. Early side effects of corticosteroid therapy may include insomnia, acne, increased appetite, weight gain with cushingoid features, hypertension, hyperglycaemia, oedema, glaucoma, dyspepsia, mood disturbance, or psychosis. ${ }^{16}$

Prolonged corticosteroid exposure can give rise to significant patient harm. In an active CD cohort, corticosteroid-related AEs at week 10 were reported in $55 \%$ of patients receiving prednisolone (40 $\mathrm{mg} /$ day for two weeks with subsequent weaning) and in $33 \%$ of those on budesonide $(9 \mathrm{mg} / \mathrm{day}$ for eight weeks, $6 \mathrm{mg} /$ day for two weeks). ${ }^{29}$ A retrospective review of 30,456 United States veterans with IBD found that the risk of venous thromboembolism (VTE), fragility fracture, and infections per 1000 person-years was higher in corticosteroid users versus non-users $(9 \cdot 0 \%$ vs. $4 \cdot 9 \%, 2 \cdot 6 \%$ vs. $1.9 \%$ and $54 \cdot 3 \%$ vs. $26 \cdot 9 \%$ respectively)..$^{57}$

There is substantial evidence highlighting the increased risk of infection with systemic corticosteroids in IBD. ${ }^{57-60} \mathrm{~A}$ meta-analysis of 71 controlled corticosteroid trials found that dosages of prednisolone $\geq 20 \mathrm{mg} /$ day double the risk of non-lethal and fatal infections. ${ }^{60}$ A study of 223 patients with systemic lupus erythematosus (SLE) reported that the risk of infection rose from 1.5fold at a mean prednisolone dose below $10 \mathrm{mg} /$ day to over 8 -fold at doses above $40 \mathrm{mg} /$ day. ${ }^{61}$ Prospective registry cohorts in CD have demonstrated that the risk of serious infection is higher in patients being administered systemic corticosteroids. ${ }^{58,59}$ Additionally, a meta-analysis of observational studies concluded that corticosteroid use increased the risk of infectious postoperative complications in IBD patients undergoing surgery (OR 1.68, 95\% $\mathrm{Cl} 1 \cdot 24-2 \cdot 28){ }^{62}$

There is a multitude of evidence linking corticosteroid use with negative effects on bone density and growth. Corticosteroid exposure in the paediatric CD population is associated with growth failure and reduced adult height. ${ }^{63,64}$ Osteopenia and osteoporosis in IBD are common, with an estimated prevalence between 30 and $60 \% .{ }^{65}$ Whilst the risk of these conditions in IBD is increased independent of medical therapy, they are compounded by corticosteroid exposure. ${ }^{65} \mathrm{~A}$ study in 49 
UC and CD patients found the only significant predictor of diminished bone density at the hip and spine was corticosteroid use $(p=0.025) .{ }^{66}$ In a large UK retrospective cohort study including 244,235 current oral corticosteroid users and the same number of matched controls, the relative risks of nonvertebral fracture, hip fracture and vertebral fracture in the steroid users were $1.33(95 \% \mathrm{Cl} 1.29$ 1.38), 1.61 (95\% Cl 1.47-1.76) and 2.60 (95\% Cl 2.31-2.92) respectively. The degree of risk was demonstrated to be dose dependent. Relative to control, a daily dose of less than $2.5 \mathrm{mg}$ of prednisolone had a vertebral fracture relative risk of 1.55 (95\% Cl 1.20-2.01), which rose to 2.59 $(95 \% \mathrm{Cl} 2 \cdot 16-3 \cdot 10)$ with daily doses of $2 \cdot 5-7 \cdot 5 \mathrm{mg}$, and further increased to $5 \cdot 18(95 \% \mathrm{Cl} 4 \cdot 25-6 \cdot 31)$ at daily doses above $7.5 \mathrm{mg}$. The same effect was seen with hip fracture risk. Upon cessation of corticosteroid treatment, a gradual reduction in fracture risk was observed over time, however the relative risk of fracture was still increased at 12 months after cessation of therapy. ${ }^{67}$ Whilst BMD improves after cessation of corticosteroids, it rarely recovers to pre-treatment levels. ${ }^{68}$ A metaanalysis of 89 studies examining the relationship between corticosteroid use and bone mineral density (BMD) or fracture found that the risk of fracture increased sharply within the first three to six months of steroid treatment. It also concluded that doses of more than $5 \mathrm{mg}$ prednisolone equivalent rapidly lead to a reduction in BMD and increased risk of fracture. ${ }^{69} \mathrm{~A}$ Cochrane systematic review of five trials found that calcium and vitamin $D$ supplementation prevented bone loss from the forearm and lumbar spine in corticosteroid treated patients. ${ }^{70}$ Subsequently, multiple international guidelines advocate calcium and vitamin D supplementation in IBD patients receiving corticosteroids. ${ }^{71,72}$

Compelling evidence has also emerged linking systemic corticosteroids to increased mortality in IBD. The TREAT registry provided prospective data on outcomes after a total of 30,963 patient-years of follow-up. Prednisone was found to increase mortality risk on multivariate analysis ( $\mathrm{HR} 2 \cdot 14,95 \% \mathrm{Cl}$ $=1.55-2.95 ; p<0.001$ ), while other $C D$ therapies, such as infliximab did not. ${ }^{59}$ In Europe, the ENCORE registry also prospectively followed up CD patients who received infliximab, conventional therapies, or a combination of both for five years. In this cohort, prednisone was the only agent associated with increased mortality risk (HR 3.58, 95\% $\mathrm{Cl} 1 \cdot 49-8 \cdot 61) .{ }^{73}$ 


\section{SAFETY OF SECOND-GENERATION CORTICOSTEROID THERAPY}

In comparison to traditional corticosteroids, budesonide tends to be better tolerated by patients, which is likely due to its high first-pass metabolism and limited systemic bioavailability. ${ }^{74} 29,36$ Shortterm use of methylprednisolone was found to suppress osteoblast activity, whilst budesonide did not. ${ }^{75} \mathrm{~A}$ randomised study of 272 patients with $\mathrm{CD}$ of the ileum and/or ascending colon given daily treatment with either budesonide or prednisolone for two years, found a milder degree of BMD loss in the budesonide group in those who were steroid naïve at entry (mean $-1 \cdot 04 \%$ vs $-3 \cdot 84 \% ; p=$ 0.0084). ${ }^{76}$ However, budesonide still appears to reduce bone mineral density. A two-year longitudinal study of 138 patients with quiescent $C D$ found that those given budesonide $8.5 \mathrm{mg} /$ day were more likely to develop more than $2 \%$ per annum BMD loss than a non-steroid group. ${ }^{77}$ Although budesonide seems to cause some degree of adrenal suppression, morning cortisol levels remained in the normal range in two large studies including 899 patients. ${ }^{36,38}$ Clinically important corticosteroid-related side effects including sepsis, cataracts and adrenal insufficiency do not have a higher incidence in patients taking budesonide compared with placebo. ${ }^{78}$

Budesonide MMX is well tolerated in UC patients. In a pooled analysis of three studies including over 900 UC patients, budesonide MMX did not impair adrenocorticoid function, nor did it increase the risk of $A E s$ over placebo. ${ }^{38} A$ recent review found that the safety profile of budesonide $M M X$ and BDP was comparable to placebo when used for four to eight weeks in mild-to-moderate UC. ${ }^{79}$ However, a randomised trial of 282 UC patients found that in comparison to prednisone, BDP use yielded no difference in steroid-related AEs and plasma cortisol less than 150 at week four $(38.7 \%$ for BDP vs. $46.9 \%$ for prednisone $[p=0 \cdot 17]) .{ }^{46}$ Conversely, a subsequent systematic review of five controlled trials - which included the previous study - concluded that BDP had a comparable safety profile to 5-ASA. ${ }^{47}$ 


\section{SYSTEMIC CORTICOSTEROID DOSAGE AND TAPERING}

There is heterogeneity in practice when it comes to dosing and tapering of systemic corticosteroids in IBD. The recommended oral corticosteroid doses for CD have been derived from the NCCDS, ECCDS and GETAID studies and have subsequently been extrapolated for use in UC. ${ }^{21-23,76}$ The NCCDS used oral prednisone at an initial dose of $0.5-0.75 \mathrm{mg} / \mathrm{kg} /$ day, which corresponded to treatment doses of 40-60 mg/day, whilst the ECCDS used methylprednisolone $48 \mathrm{mg}$ daily (equivalent to $60 \mathrm{mg}$ of prednisone) and GETAID used oral prednisolone $1 \mathrm{mg} / \mathrm{kg} /$ day. There have been no studies that directly compare oral prednisone and prednisolone in IBD. ${ }^{80}$ With respect to efficacy, the higher doses used in ECCDS and GETAID appeared to achieve better initial remission rates. Conversely, population data showed that remission rates using 40-60 mg/day in an Olmsted County CD cohort (58\%) were superior to $1 \mathrm{mg} / \mathrm{kg} /$ day used in a Copenhagen cohort (48\%) at 30 days. ${ }^{81,82} \mathrm{~A}$ single early study suggested that prednisone $40 \mathrm{mg} /$ day was as effective as $60 \mathrm{mg} /$ day in achieving clinical remission, whilst causing fewer side effects, which has led to many physicians preferring this starting dose. However, it should be noted that more patients in this study receiving the $40 \mathrm{mg}$ starting dose did not improve or clinically worsened. Moreover, the additional side effects reported in the $60 \mathrm{mg}$ starting dose group consisted of just two cases of facial mooning and one case of hypertension. ${ }^{83} \mathrm{As}$ a result of these inconsistencies, current major guidelines have not recommended one dosing regimen over another. ${ }^{71,72,84}$

The choice of corticosteroid tapering regimen used does not seem to alter outcome. ${ }^{85}$ Relapse rates in the NCCDS, ECCDS and GETAID trials were similar despite highly varied tapering protocols. ${ }^{23,24,86} \mathrm{~A}$ controlled CD study including 70 patients found that tapering intramuscular methylprednisolone over four weeks versus 12 weeks did not change rates of clinical remission induction or maintenance of remission at six months. ${ }^{87}$ 


\section{TARGETS FOR CORTICOSTEROID THERAPY IN AN EVOLVING TREATMENT LANDSCAPE}

In light of the well-established toxicity of prolonged corticosteroid use, it is no surprise that major bodies have set targets and quality indicators specifically aimed at limiting patient corticosteroid exposure. The updated 2017 European Crohn's and Colitis Organisation (ECCO) consensus guidelines on the diagnosis and management of UC emphasise that the overarching goal of maintenance therapy is to maintain steroid-free remission. ${ }^{88}$ The Crohn's and Colitis Foundation of America (CCFA) stipulates that the percentage of patients taking prednisone (excluding those diagnosed in the last 112 days) be used as a quality outcome measure for an IBD unit. The CCFA also uses the recommendation of steroid-sparing therapy after four months of corticosteroid therapy as a process quality indicator. ${ }^{89}$ The 2019 IBD Standards released by Crohn's and Colitis UK advise that steroid treatment should be audited by individual IBD units on an ongoing basis. ${ }^{90}$ Patient representative bodies have also pinpointed steroid-free remission as a top priority for IBD patients. ${ }^{91}$

Whilst corticosteroid-free remission has become an important outcome in modern IBD trials, the lack of uniformity and transparency in steroid dose and tapering protocols has meant that comparison of corticosteroid-free remission rates between studies is clouded by not only differences in study populations, but also varied steroid dosing and tapering rules. ${ }^{92}$ Table 3 and Table 4 outline the differences in corticosteroid dosing and tapering rules between major randomised controlled trials in $C D$ and $U C$ respectively. Bearing in mind that this heterogeneity prevents direct comparisons between trials, Table 5 and Table 6 summarise the key corticosteroid-free remission clinical trial data for commonly used maintenance treatments in $C D$ and $U C$ respectively. 


\section{CONTEMPORARY TRENDS IN CORTICOSTEROID USE}

Despite the introduction of effective IBD therapies, change in the application of corticosteroid therapy has been limited. A population-based study of 5300 IBD patients in Manitoba assessed trends in corticosteroid prescription based on the year of IBD diagnosis. Between diagnosis years 1995 and 2004, there was no difference in the likelihood of a patient receiving corticosteroids over a five-year follow-up period ( $p=0.152$ ), despite the increasing use of immunomodulators in the cohort during that same period. In fact, over time between 1995 and 2008, patients were increasingly likely to receive corticosteroids within their first year of diagnosis $(p=0.025) .{ }^{93}$ In a population-based study of 1013 UC patients from South Korea diagnosed between 1986 and 2015 that had a mean follow-up period of 108 months, $40.8 \%$ of the cohort were exposed to systemic corticosteroids at least once, with the cumulative risk of exposure decreasing over time. ${ }^{94}$ Recent European prospective population-based inception cohort studies following patients diagnosed with CD (488 patients) and UC (717 patients) in 2010 found that $60 \%$ and $52 \%$ had been exposed to systemic corticosteroids after five years respectively. In addition, $14 \%$ of the UC cohort and $9 \%$ of the $\mathrm{CD}$ cohort had received steroids for greater than six consecutive months during the follow-up period. ${ }^{95,96}$ In the United States, a review of Veterans Health Administration data between 2002 and 2010 revealed that of the 30,456 IBD patients included, 32\% were exposed to corticosteroids, with $17 \%$ of users receiving a prolonged course. Notably, only $26 \%$ of patients receiving their second 
steroid prescription within a year were escalated to a corticosteroid-sparing medication. Review by a gastrointestinal specialist during a period of steroid use significantly increased the likelihood of commencement of corticosteroid-sparing therapy (68\% vs. $31 \%, p<0.001) .{ }^{57}$

Chhaya and colleagues published UK data looking at corticosteroid prescribing trends between 1990 and 2010 in 23,509 incident IBD cases. In CD, as thiopurine use increased, prolonged (> three months) oral corticosteroid exposure decreased over time (36.5\% in $1990-1997$ vs. $26.8 \%$ in $2002-$ 2010, $p<0.001$ ). However, despite a similar increase in thiopurine use observed in UC, the use of oral corticosteroids within five years of diagnosis increased over time $(29.9 \%$ in $1990-1993$ vs. $48.5 \%$ in 2002-2005), as did rates of recurrent ( $15.3 \%$ in $1990-1993$ vs. $17.8 \%$ in $2002-2005$ [ $p=0.02$ ]) and very prolonged (> six months) exposure (11.0\% in $1990-1997$ vs. $13.0 \%$ in $2002-2010$ [ $p=0.03]) .{ }^{97} \mathrm{~A}$ Dutch study of similar methodology examining trends in 2,823 incident IBD cases between 1991 and 2011 found that corticosteroid exposure within the first year of diagnosis was stable over time (54.0\% in CD and $31.4 \%$ in UC). Cumulative corticosteroid exposure was observed to decline over time in $C D$, whilst in UC it initially decreased before plateauing. In CD, both immunomodulator and biological use were associated with a reduced risk of requiring corticosteroids (33.6\% vs. $49.9 \%, \mathrm{p}<$ 0.01 and $25.7 \%$ vs. $38 \cdot 2 \%, p=0.04$ respectively). ${ }^{98} \mathrm{~A}$ US retrospective observational study including 1,119 IBD patients found that despite increased utilisation of biologic therapies for IBD between 2003 and 2011, there was no significant reduction in corticosteroid prescription rates during the same time frame. ${ }^{99}$ Another recent study from the United States examined IBD treatment pathways between 2008 and 2016 for a large insured population consisting of 16,260 patients with CD and 28,129 with UC. Alarmingly, corticosteroid monotherapy was the most common treatment pathway for CD (26\%) and second most common pathway for UC (16\%). 63\% of these CD patients received two or more steroid cycles and 108 received ten or more cycles. There appeared to be an underutilisation of steroid-sparing strategies within the cohort. For example, biologic pathways were only used in $19 \%$ of CD patients and $6 \%$ with UC. ${ }^{100}$

Fresh data suggests that health care providers underestimate corticosteroid use in IBD. A study survey of 812 patients and their treating physicians found that significantly more patients than medical practitioners reported corticosteroid use $(25.9 \%$ vs. $20.8 \%$, kappa $=0.735, p<0.0001)$, and patients with routine follow-up were less likely to be treated with prolonged corticosteroid therapy $(10 \cdot 3 \%$ vs. $20 \cdot 7 \%, p<0 \cdot 01) .{ }^{101}$

A noteworthy limitation of these studies examining trends in corticosteroid use in IBD is their susceptibility to confounding by variables not reported or studied during the retrospective period of analysis. Our group published a prospective multi-centre audit of excess steroid use in IBD in the United Kingdom. In this study, steroid dependency or excess was defined in accordance with ECCO and UK guidelines. ${ }^{71,102,103}$ For cases with steroid dependency or excess, anonymised records were submitted for blinded peer review and in cases where efforts to avoid steroid dependency or excess were judged suboptimal or absent, a finding of inappropriate steroid excess was recorded. Of the 1,176 patients included in the 2015 study, $14.9 \%$ were deemed to have steroid dependency or 
excess. $49 \cdot 1 \%$ of these patients were judged to have inappropriate steroid dependency or excess, with an annual incidence of inappropriate steroid excess of $7 \cdot 1 \%$. Inappropriate steroid therapy was associated with a number of patient and service-level factors. Treatment at a centre with dedicated IBD clinics was a protective factor in UC (OR $=0.64,95 \% \mathrm{Cl} 0.21-0.94)$, whilst having an established IBD multidisciplinary team was protective in $C D(O R=0.62,95 \% \mathrm{Cl} 0 \cdot 46-0.91)$. Patients with $C D$ who were treated with 5-ASA therapy were more likely to experience steroid dependency or excess (OR 1.87 [Cl 1.01-3.91]), highlighting this measure as a potential surrogate marker of quality of care. We also analysed the source of steroid prescription in patients identified as having corticosteroid dependency or excess. In $17.0 \%$ of cases, the decision to commence steroid was made in primary care. $91.3 \%$ of these cases were classed as avoidable corticosteroid excess, versus $42.0 \%$ of cases initiated in secondary care $(p<0 \cdot 0001) .{ }^{104}$

We performed a follow-up study in 2017 including 2,385 patients across 19 UK centres, and found a very similar overall rate of steroid excess or dependency (14.8\%). Again, roughly half of this excess (50.7\%) was deemed to be avoidable. Seven of the centres included in the 2015 study had subsequently undertaken a quality improvement programme focused on reducing steroid excess. In the follow-up period, these intervention centres achieved lower corticosteroid exposure $(23 \cdot 8 \%$ vs. $31.0 \%, p<0.001)$ and excess $(11.5 \%$ vs. $17 \cdot 1 \%, p<0.001)$. Importantly, this effect remained even after we corrected for other characteristics in a multivariate analysis. ${ }^{105}$

\section{STRATEGIES TO COMBAT CORTICOSTEROID EXCESS}

There appear to be multiple underlying reasons for the high prevalence of corticosteroid use in contemporary IBD care. Unfortunately, few steroid-sparing agents exist that can induce a swift clinical response during an IBD flare and corticosteroids undeniably still play a key role in this setting. In addition, there are often logistical and financial barriers for rapid access to some steroid-sparing therapies, as well as a lack of awareness of steroid-sparing options, particularly in primary care. ${ }^{106}$ Practical solutions to combat corticosteroid excess in IBD are vital in order to prevent avoidable short and long-term toxicity.

\section{PRIMARY CARE}

A significant proportion of steroid prescribing for IBD in primary care is inappropriate. ${ }^{104}$ Engaging with and educating patients and general practitioners (GPs) with respect to the limitations and consequences of corticosteroid therapy in IBD may reduce the likelihood of inappropriate corticosteroid prescriptions in this setting. When surveyed in 2017, half of GPs in the UK said they lacked confidence in managing IBD and two thirds requested further education. In response, the Royal College of General Practitioners (RCGP) created an IBD online toolkit and electronic learning resource specifically for primary care providers. ${ }^{106}$ Equipping GPs with better knowledge regarding 5ASA optimisation principles in UC could reduce unnecessary corticosteroid exposure, as may empowering UC patients with 5-ASA self-management strategies in the response to a disease flare. This education needs to be coupled with improved awareness of the existence and importance of 
steroid-sparing options along with improved access for patients to secondary care. IBD telephone helplines and digital communication pathways can help to build closer bridges between primary and secondary care.

\section{SECONDARY CARE}

The introduction of a local quality improvement programme focused on combating avoidable steroid use can result in a rapid decline in rates of excess exposure. ${ }^{105}$ Rapid and efficient assessment, investigation and management of suspected new IBD cases and flares in secondary care is crucial in order to commence corticosteroid-sparing treatments in a timely fashion. Therefore, service pathways enabling prompt review of symptomatic outpatients with, or suspected of having IBD are important to have in place. Similar pathways should also be in place for patients with newly diagnosed IBD at endoscopy. Clinicians should be educated to escalate IBD therapy promptly when a current strategy is not adequately controlling the disease. Real world UC studies have suggested that oral steroid failure rates in moderate flares appear to be similar to those with intravenous steroids in severe flares. Thus, timely assessment of response to corticosteroid therapy is important to enable early detection of non-responders and facilitate prompt treatment escalation. ${ }^{55,107}$ Dedicated IBD clinics appear to be superior to general gastroenterology clinics in reducing inappropriate corticosteroid excess. ${ }^{104}$ Regular IBD multidisciplinary team meetings to discuss complex cases have also been shown to reduce the risk of inappropriate steroid excess. ${ }^{104,105}$ Moreover, the use of a multidisciplinary team to explore steroid-sparing options in patients on prolonged corticosteroid therapy is recommended by the new British Society of Gastroenterology (BSG) IBD consensus guidelines. ${ }^{72}$

In order to self-assess steroid prescribing practices, IBD units should undertake steroid auditing on a regular and continued basis. Auditing of steroid use within an IBD unit can result in a reduction in inappropriate corticosteroid prescribing. ${ }^{108}$ Analogous to the use of caecal intubation rate in colonoscopy quality control, rates of corticosteroid prescribing in an IBD service could be benchmarked and monitored. For this reason, auditing of corticosteroid rates within an IBD service has been recommended by the 2019 UK IBD Standards..$^{90}$ At this point, key performance indicator targets for corticosteroid prescription are not clear, however major variation in prescription rates between centres should be a trigger to analyse the underlying factors responsible and address reversible causes.

In the future, there may be a role for novel steroid-sparing strategies, such as small molecule burst therapy for the management of IBD flares, however evidence supporting the safety and efficacy of such a strategy is lacking at this time. If corticosteroid therapy is genuinely required, clinicians should always consider whether second-generation corticosteroid agents may be appropriate in an effort to minimise AEs. For instance, a UK population-based study reported a potential underutilisation of ileal release budesonide in CD. Between 1990 and 2009, 50.7\% of CD patients received corticosteroids within five years of diagnosis, with only $11 \cdot 5 \%$ in total receiving budesonide. ${ }^{109}$ 


\section{CONCLUSION}

There is little argument that corticosteroids have revolutionised the treatment of IBD, particularly given their unparalleled effectiveness for inducing remission in the short-term. These agents are, however, ineffective in the maintenance of IBD and cause substantial harm to patients, particularly with prolonged use. Despite the emergence of multiple new corticosteroid-sparing IBD therapies over the last two decades, the rate of steroid use has not significantly declined and much of the exposure appears to be avoidable. Local implementation of strategies targeting corticosteroid excess in IBD can successfully reduce rates of unnecessary exposure. 


\section{AUTHORS' CONTRIBUTIONS}

AMD performed the literature search and wrote the manuscript. TR, CPS, GCP, MS and RCP reviewed and edited the manuscript.

\section{CONFLICT OF INTEREST}

AMD declares no potential conflicts of interest. TR reports grants and personal fees from AbbVie, as well as personal fees from Celgene, Gilead, GSK, Janssen, MSD, Novartis, Sandoz, and Takeda. CPS reports grants and personal fees from Janssen, AbbVie and Takeda, as well as personal fees from Pfizer, Tillotts, Dr Falk, Fresenius Kabi, and Eli Lilly. GCP reports personal fees and non-financial support from AbbVie and Takeda, as well as personal fees from Janssen and Ferring. MS reports personal fees from AbbVie, Ferring, and Predict Immune. RCP reports grants from Janssen, Takeda, Dr Falk, and Actavis.

\section{FUNDING}

No funding was received in relation to the production of this review. 


\section{REFERENCES}

1 Brattsand R, Linden M. Cytokine modulation by glucocorticoids: mechanisms and actions in cellular studies. Aliment Pharmacol Ther 1996; 10: 81-90.

2 Ramamoorthy S, Cidlowski JA. Corticosteroids. Mechanisms of Action in Health and Disease. Rheum. Dis. Clin. North Am. 2016; 42: 15-31.

3 Liu D, Ahmet A, Ward L, et al. A practical guide to the monitoring and management of the complications of systemic corticosteroid therapy. Allergy, Asthma Clin. Immunol. 2013; 9. DOI:10.1186/1710-1492-9-30.

4 Mager DE, Lin SX, Blum RA, Lates CD, Jusko WJ. Dose Equivalency Evaluation of Major Corticosteroids: Pharmacokinetics and Cell Trafficking and Cortisol Dynamics. J Clin Pharmacol 2003; 43: 1216-27.

5 Dearing WH, Brown PW. Experiences with cortisone and ACTH in chronic ulcerative colitis. Proc Staff Meet Mayo Clin 1950; 25: 486-8.

6 Machella TE, Hollan OR. The effect of cortisone on the clinical course of chronic regional enteritis and chronic idiopathic ulcerative colitis. Am J Med Sci 1951; 221: 501-7.

7 Elliott JM, Kiefer ED, Hurxthal LM. ACTH in the treatment of chronic ulcerative colitis. Gastroenterology 1951; 19: 722-34.

8 Kirsner JB, Palmer WL. Effect of corticotropin (ACTH) in chronic ulcerative colitis; observations in forty patients. J Am Med Assoc 1951; 147: 541-9.

9 Rossmiller HR, Brown CH, Ecker JA. The effect of ACTH on nonspecific ulcerative colitis. Gastroenterology 1951; 17: 25-7.

10 Brown GM, Mcauley JS. Cortisone therapy in ulcerative colitis. J Am Med Assoc 1952; 150: 1587-91.

11 Gray SJ, Reifenstein RW, Benson JA, Young JCG. Treatment of ulcerative colitis with corticotropin (ACTH) and cortisone: A two year follow-up. J Am Med Assoc 1952; 148 : 1489-97.

12 Bekaert J, Vuylsteek K. [Treatment of ulcerative colitis by cortisone]. Sem Hop 1952; 28: 558-61.

13 Truelove SC. Cortisone in Ulcerative Colitis Final Report on a Therapeutic Trial. Br Med J 1955; 2: 1041-8.

14 Lennard-Jones JE, Longmore AJ, Newell AC, Wilson CW, Jones FA. An assessment of prednisone, salazopyrin, and topical hydrocortisone hemisuccinate used as out-patient treatment for ulcerative colitis. Gut 1960; 1: 217-22.

15 Truelove SC, Watkinson G, Draper G. Comparison of Corticosteroid and Sulphasalazine Therapy in Ulcerative Colitis. Br Med J 1962; 2: 1708-11.

16 Ford AC, Bernstein CN, Khan KJ, et al. Glucocorticosteroid therapy in inflammatory bowel 
disease: systematic review and meta-analysis. Am J Gastroenterol 2011; 106: 590-9;

17 Truelove SC, Jewell DP. Intensive intravenous regimen for severe attacks of ulcerative colitis. Lancet (London, England) 1974; 1: 1067-70.

18 Truelove SC, Lee EG, Willoughby CP, Kettlewell MGW. Further experience in the treatment of severe attacks of ulcerative colitis. Lancet 1978; 312: 1086-8.

19 Järnerot G, Rolny P, Sandberg-Gertzén H. Intensive intravenous treatment of ulcerative colitis. Gastroenterology 1985; 89: 1005-13.

20 Lichtenstein GR, Abreu MT, Cohen R, Tremaine W. American Gastroenterological Association Institute Technical Review on Corticosteroids, Immunomodulators, and Infliximab in Inflammatory Bowel Disease. Gastroenterology 2006; 130: 940-87.

21 Turner D, Walsh CM, Steinhart AH, Griffiths AM. Response to Corticosteroids in Severe Ulcerative Colitis: A Systematic Review of the Literature and a Meta-Regression. Clin Gastroenterol Hepatol 2007; 5: 103-10.

22 Wiles A, Bredin F, Chukualim B, Middleton S. In the treatment of flares of inflammatory bowel disease, intravenous hydrocortisone causes greater falls in blood potassium and more severe episodes of hypokalaemia than methylprednisolone. Gut 2011; 60 Suppl 1: 223.

23 Summers RW, Switz DM, Sessions JT, et al. National Cooperative Crohn's Disease Study: Results of drug treatment. Gastroenterology 1979; 77: 847-69.

24 Malchow H, Ewe K, Brandes JW, et al. European Cooperative Crohn's Disease Study (ECCDS): Results of drug treatment. Gastroenterology 1984; 86: 249-66.

25 Benchimol EI, Seow CH, Steinhart AH, Griffiths AM. Traditional corticosteroids for induction of remission in Crohn's disease. Cochrane Database Syst. Rev. 2008. DOI:10.1002/14651858.CD006792.pub2.

26 Lundin PDP, Edsbäcker S, Bergstrand M, et al. Pharmacokinetics of budesonide controlled ileal release capsules in children and adults with active Crohn's disease. Aliment Pharmacol Ther 2003; 17: 85-92.

27 Edsbäcker S, Bengtsson B, Larsson P, et al. A pharmacoscintigraphic evaluation of oral budesonide given as controlled-release (Entocort) capsules. Aliment Pharmacol Ther 2003; 17: 525-36.

28 Miller-Larsson A, Gustafsson B, Persson CGA, Brattsand R. Gut mucosal uptake and retention characteristics contribute to the high intestinal selectivity of budesonide compared with prednisolone in the rat. Aliment Pharmacol Ther 2001; 15: 2019-25.

29 Rutgeerts P, Lofberg R, Malchow H, et al. A comparison of budesonide with prednisolone for active Crohn's disease. $N$ Engl J Med 1994; 331: 842-5.

30 Gross V, Andus T, Caesar I, et al. Oral pH-modified release budesonide versus 6methylprednisolone in active Crohn's disease. German/Austrian Budesonide Study 
Group. Eur J Gastroenterol Hepatol 1996; 8: 905-9.

31 Campieri M, Ferguson A, Doe W, Persson T, Nilsson LG. Oral budesonide is as effective as oral prednisolone in active Crohn's disease. The Global Budesonide Study Group. Gut 1997; 41: 209-14.

32 Bar-Meir S, Chowers Y, Lavy A, et al. Budesonide versus prednisone in the treatment of active Crohn's disease. Gastroenterology 1998; 115: 835-40.

33 Greenberg GR, Feagan BG, Martin F, et al. Oral budesonide for active Crohn's disease. $N$ Engl J Med 1994; 331: 836-41.

34 Thomsen $0 \emptyset$, Cortot A, Jewell D, et al. A comparison of budesonide and mesalamine for active Crohn's disease. N Engl J Med 1998; 339: 370-4.

35 Rezaie A, Kuenzig ME, Benchimol EI, et al. Budesonide for induction of remission in Crohn's disease. Cochrane database Syst Rev 2015; : CD000296.

36 Lofberg R, Danielsson A, Suhr 0, et al. Oral budesonide versus prednisolone in patients with active extensive and left-sided ulcerative colitis. Gastroenterology 1996; 110: 17138.

37 Gross V, Bunganic I, Belousova EA, et al. 3g mesalazine granules are superior to 9mg budesonide for achieving remission in active ulcerative colitis: A double-blind, doubledummy, randomised trial. J Crohn's Colitis 2011; 5: 129-38.

38 Sherlock ME, MacDonald JK, Griffiths AM, Steinhart AH, Seow CH. Oral budesonide for induction of remission in ulcerative colitis. Cochrane database Syst Rev 2015; : CD007698.

39 Brunner M, Ziegler S, Di Stefano AFD, et al. Gastrointestinal transit, release and plasma pharmacokinetics of a new oral budesonide formulation. Br J Clin Pharmacol 2006; 61: 31-8.

40 Sandborn WJ, Travis S, Moro L, et al. Once-daily budesonide MMX(R) extended-release tablets induce remission in patients with mild to moderate ulcerative colitis: results from the CORE I study. Gastroenterology 2012; 143: 1218-1226.e2.

41 Travis SPL, Danese S, Kupcinskas L, et al. Once-daily budesonide MMX in active, mild-tomoderate ulcerative colitis: results from the randomised CORE II study. Gut 2014; 63: 433-41.

42 Sandborn WJ, Danese S, D'Haens G, et al. Induction of clinical and colonoscopic remission of mild-to-moderate ulcerative colitis with budesonide MMX $9 \mathrm{mg}$ : Pooled analysis of two phase 3 studies. Aliment Pharmacol Ther 2015; 41: 409-18.

43 Rubin DT, Cohen RD, Sandborn WJ, et al. Budesonide Multimatrix Is Efficacious for Mesalamine-refractory, Mild to Moderate Ulcerative Colitis: A Randomised, Placebocontrolled Trial. J Crohns Colitis 2017; 11: 785-91.

44 Campieri M, Adamo S, Valpiani D, et al. Oral beclometasone dipropionate in the treatment of extensive and left-sided active ulcerative colitis: A multicentre randomised study. 
Aliment Pharmacol Ther 2003; 17: 1471-80.

45 Rizzello F, Gionchetti P, D’Arienzo A, et al. Oral beclometasone dipropionate in the treatment of active ulcerative colitis: A double-blind placebo-controlled study. Aliment Pharmacol Ther 2002; 16: 1109-16.

46 Van Assche G, Manguso F, Zibellini M, et al. Oral prolonged release beclomethasone dipropionate and prednisone in the treatment of active ulcerative colitis: Results from a double-blind, randomized, parallel group study. Am J Gastroenterol 2015; 110: 708-15.

47 Manguso F, Bennato R, Lombardi G, Riccio E, Costantino G, Fries W. Efficacy and Safety of Oral Beclomethasone Dipropionate in Ulcerative Colitis: A Systematic Review and MetaAnalysis. PLoS One 2016; 11: e0166455.

48 Steinhart AH, Ewe K, Griffiths AM, Modigliani R, Thomsen 00. Corticosteroids for maintenance of remission in Crohn's disease. Cochrane Database Syst Rev 2003; published online Oct 20. DOI:10.1002/14651858.cd000301.

49 Kuenzig ME, Rezaie A, Seow $\mathrm{CH}$, et al. Budesonide for maintenance of remission in Crohn's disease. Cochrane database Syst Rev 2014; : CD002913.

50 Kuenzig ME, Rezaie A, Kaplan GG, et al. Budesonide for the Induction and Maintenance of Remission in Crohn's Disease: Systematic Review and Meta-Analysis for the Cochrane Collaboration. J Can Assoc Gastroenterol 2018; 1: 159-73.

51 Landi B, Anh TN guye., Cortot A, et al. Endoscopic monitoring of Crohn's disease treatment: A prospective, randomized clinical trial. Gastroenterology 1992; 102: 164753.

52 Hellers G, Cortot A, Jewell D, et al. Oral budesonide for prevention of postsurgical recurrence in Crohn's disease. The IOIBD Budesonide Study Group. Gastroenterology 1999; 116: 294-300.

53 Truelove SC, Witts LJ. Cortisone and corticotrophin in ulcerative colitis. Br Med J 1959; 1: 387-94.

54 Lennard-Jones JE, Misiewicz JJ, Connell AM, Baron JH, Avery Jones F. Prednisone as maintenance treatment for ulcerative colitis in remission. Lancet 1965; 285: 188-9.

55 Ardizzone S, Cassinotti A, Duca P, et al. Mucosal Healing Predicts Late Outcomes After the First Course of Corticosteroids for Newly Diagnosed Ulcerative Colitis. Clin Gastroenterol Hepatol 2011; 9. DOI:10.1016/j.cgh.2010.12.028.

56 Keenan GF. Management of complications of glucocorticoid therapy. Clin Chest Med 1997; 18: $507-20$.

57 Waljee AK, Wiitala WL, Govani S, et al. Corticosteroid use and complications in a US inflammatory bowel disease cohort. PLoS One 2016; 11.

DOI:10.1371/journal.pone.0158017.

58 Lichtenstein GR, Feagan BG, Cohen RD, et al. Serious infections and mortality in 
association with therapies for Crohn's disease: TREAT registry. Clin Gastroenterol Hepatol 2006; 4: 621-30.

59 Lichtenstein GR, Feagan BG, Cohen RD, et al. Serious infection and mortality in patients with crohn's disease: More than 5 years of follow-up in the TREAT registry. Am J Gastroenterol 2012; 107: 1409-22.

60 Stuck AE, Minder CE, Frey FJ. Risk of infectious complications in patients taking glucocorticosteroids. Rev Infect Dis; 11: 954-63.

61 Ginzler E, Diamond H, Kaplan D, Weiner M, Schlesinger M, Seleznick M. Computer analysis of factors influencing frequency of infection in systemic lupus erythematosus. Arthritis Rheum 1978; 21: 37-44.

62 Subramanian V, Saxena S, Kang J-Y, Pollok RCG. Preoperative steroid use and risk of postoperative complications in patients with inflammatory bowel disease undergoing abdominal surgery. Am J Gastroenterol 2008; 103: 2373-81.

63 Alemzadeh N, Rekers-Mombarg LTM, Mearin ML, Wit JM, Lamers CBHW, Van Hogezand RA. Adult height in patients with early onset of Crohn's disease. Gut 2002; 51: 26-9.

64 Burnham JM, Shults J, Semeao E, et al. Whole body BMC in pediatric Crohn disease: Independent effects of altered growth, maturation, and body composition. J Bone Miner Res 2004; 19: 1961-8.

65 Valentine JF, Sninsky CA. Prevention and treatment of osteoporosis in patients with inflammatory bowel disease. Am J Gastroenterol 1999; 94: 878-83.

66 Bernstein CN, Seeger LL, Sayre JW, Anton PA, Artinian L, Shanahan F. Decreased bone density in inflammatory bowel disease is related to corticosteroid use and not disease diagnosis. J Bone Miner Res 1995; 10: 250-6.

67 Van Staa TP, Leufkens HGM, Abenhaim L, Zhang B, Cooper C. Use of oral corticosteroids and risk of fractures.J Bone Miner Res 2000; 15: 993-1000.

68 Adachi JD, Rostom A. Metabolic bone disease in adults with inflammatory bowel disease. Inflamm Bowel Dis 1999; 5: 200-11.

69 Van Staa TP, Leufkens HGM, Cooper C. The epidemiology of corticosteroid-induced osteoporosis: A meta-analysis. Osteoporos. Int. 2002; 13: 777-87.

70 Homik J, Suarez-Almazor ME, Shea B, Cranney A, Wells GA, Tugwell P. Calcium and vitamin D for corticosteroid-induced osteoporosis. Cochrane Database Syst Rev 1998; published online April 27. DOI:10.1002/14651858.cd000952.

71 Gomollón F, Dignass A, Annese V, et al. 3rd European evidence-based consensus on the diagnosis and management of Crohn's disease 2016: Part 1: Diagnosis and medical management. J Crohn's Colitis 2017; 11: 3-25.

72 Lamb C, Kennedy N, Raine T, Version AM. British Society of Gastroenterology consensus guideline on the management of IBD in adults. 2019 
DOI:10.1080/23311916.2019.1565630.

73 D'Haens G, Reinisch W, Colombel J-F, et al. Five-year Safety Data From ENCORE, a European Observational Safety Registry for Adults With Crohn's Disease Treated With Infliximab [Remicade(R)] or Conventional Therapy. J Crohns Colitis 2017; 11: 680-9.

74 Edsbäcker S, Andersson T. Pharmacokinetics of budesonide (Entocort ${ }^{\mathrm{TM}}$ EC) capsules for Crohn's disease. Clin. Pharmacokinet. 2004; 43: 803-21.

75 D'Haens G, Verstraete A, Cheyns K, Aerden I, Bouillon R, Rutgeerts P. Bone turnover during short-term therapy with methylprednisolone or budesonide in Crohn's disease. Aliment Pharmacol Ther 1998; 12: 419-24.

76 Schoon EJ, Bollani S, Mills PR, et al. Bone mineral density in relation to efficacy and side effects of budesonide and prednisolone in Crohn's disease. Clin Gastroenterol Hepatol 2005; 3: 113-21.

77 Cino M, Greenberg GR. Bone mineral density in Crohn's disease: a longitudinal study of budesonide, prednisone, and nonsteroid therapy. Am J Gastroenterol 2002; 97: 915-21.

78 Iborra M, Álvarez-Sotomayor D, Nos P. Long-term safety and efficacy of budesonide in the treatment of ulcerative colitis. Clin. Exp. Gastroenterol. 2014; 7: 39-46.

79 Cross RK. Safety Considerations with the Use of Corticosteroids and Biologic Therapies in Mild-to-Moderate Ulcerative Colitis. Inflamm Bowel Dis 2017; 23: 1689-701.

80 Teshima C, Fedorak RN. Are there differences in type, dosage, and method of administration for the systemic steroids in IBD treatment? Inflamm Bowel Dis 2008; 14 Suppl 2: S216-8.

81 Faubion WA, Loftus E V., Harmsen WS, Zinsmeister AR, Sandborn WJ. The natural history of corticosteroid therapy for inflammatory bowel disease: A population-based study. Gastroenterology 2001; 121: 255-60.

82 Munkholm P, Langholz E, Davidsen M, Binder V. Frequency of glucocorticoid resistance and dependency in Crohn's diseasee. Gut 1994; 35: 360-2.

83 Baron JH, Connell AM, Kanaghinis TG, Lennard-jones JE, Jones FA. Out-patient treatment of ulcerative colitis: Comparison between three doses of oral prednisone. Br Med J 1962; 2: 441-3.

84 Lichtenstein GR, Loftus E V., Isaacs KL, Regueiro MD, Gerson LB, Sands BE. ACG Clinical Guideline: Management of Crohn's Disease in Adults. Am. J. Gastroenterol. 2018; 113: 481-517.

85 Yang Y-X, Lichtenstein GR. Corticosteroids in Crohn's disease. Am J Gastroenterol 2002; 97: 803-23.

86 Modigliani R, Mary JY, Simon JF, et al. Clinical, biological, and endoscopic picture of attacks of Crohn's disease. Evolution on prednisolone. Gastroenterology 1990; 98: 811-8.

87 Brignola C, De Simone G, Belloli C, et al. Steroid treatment in active Crohn's disease: a 
comparison between two regimens of different duration. Aliment Pharmacol Ther 1994; 8: 465-8.

88 Harbord M, Eliakim R, Bettenworth D, et al. Third European Evidence-based Consensus on Diagnosis and Management of Ulcerative Colitis. Part 2: Current Management. J Crohn's Colitis 2017; 11: 769-84.

89 Melmed GY, Siegel CA, Spiegel BM, et al. Quality indicators for inflammatory bowel disease: development of process and outcome measures. Inflamm Bowel Dis 2013; 19: 662-8.

IBD Standards | IBD UK. https://www.ibduk.org/ibd-standards (accessed Sept 20, 2019).

91 Westwood N, Travis SPL. Review article: What do patients with inflammatory bowel disease want for their clinical management? Aliment Pharmacol Ther 2008; 27: 1-8.

92 George J, Singh S, Dulai PS, et al. Corticosteroid-Free Remission vs Overall Remission in Clinical Trials of Moderate-Severe Ulcerative Colitis and Crohn's Disease. Inflamm Bowel Dis 2019; published online Aug 30. DOI:10.1093/ibd/izz193.

93 Targownik LE, Nugent Z, Singh H, Bernstein CN. Prevalence of and outcomes associated with corticosteroid prescription in inflammatory bowel disease. Inflamm Bowel Dis 2014; 20: $622-30$.

94 Cha JM, Park SH, Rhee KH, et al. Long-term prognosis of ulcerative colitis and its temporal changes between 1986 and 2015 in a population-based cohort in the Songpa-Kangdong district of Seoul, Korea. Gut 2019. DOI:10.1136/gutjnl-2019-319699.

95 Burisch J, Kiudelis G, Kupcinskas L, et al. Natural disease course of Crohn's disease during the first 5 years after diagnosis in a European population-based inception cohort: An EpiIBD study. Gut 2019; 68: 423-33.

96 Burisch J, Katsanos KH, Christodoulou DK, et al. Natural Disease Course of Ulcerative Colitis During the First Five Years of Follow-up in a European Population-based Inception Cohort-An Epi-IBD Study. J Crohns Colitis 2019; 13: 198-208.

97 Chhaya V, Saxena S, Cecil E, et al. Steroid dependency and trends in prescribing for inflammatory bowel disease - a 20-year national population-based study. Aliment Pharmacol Ther 2016; 44: 482-94.

98 Jeuring SFG, Biemans VBC, van den Heuvel TRA, et al. Corticosteroid sparing in inflammatory bowel disease is more often achieved in the immunomodulator and biological era-results from the Dutch population-based IBDSL cohort. Am J Gastroenterol 2018; 113: 384-95.

99 Narula N, Borges L, Steinhart AH, Colombel J-F. Trends in Narcotic and Corticosteroid Prescriptions in Patients with Inflammatory Bowel Disease in the United States Ambulatory Care Setting from 2003 to 2011. Inflamm Bowel Dis 2017; 23: 868-74.

100 Siegel C, Yang F, Eslava S, Cai J. D0P060 Real-world treatment pathway visualizations show low use of biologic therapies in Crohn's disease and ulcerative colitis in the United 
States. JCrohn's Colitis 2017; 11: S61-2.

101 Ghosh S, Bressler B, Petkau J, et al. Healthcare Providers Underestimate Patients' Glucocorticoid Use in Crohn's Disease. Dig Dis Sci 2019; 64: 1142-9.

102 Mowat C, Cole A, Windsor A, et al. Guidelines for the management of inflammatory bowel disease in adults. Gut. 2011; 60: 571-607.

103 Magro F, Gionchetti P, Eliakim R, et al. Third European evidence-based consensus on diagnosis and management of ulcerative colitis. Part 1: Definitions, diagnosis, extraintestinal manifestations, pregnancy, cancer surveillance, surgery, and ileo-anal pouch disorders. J Crohn's Colitis 2017; 11: 649-70.

104 Selinger CP, Parkes GC, Bassi A, et al. A multi-centre audit of excess steroid use in 1176 patients with inflammatory bowel disease. Aliment Pharmacol Ther 2017; 46: 964-73.

105 Selinger CP, Parkes GC, Bassi A, et al. Assessment of steroid use as a key performance indicator in inflammatory bowel disease-analysis of data from 2385 UK patients. Aliment Pharmacol Ther 2019; published online Oct 8. DOI:10.1111/apt.15497.

106 Barrett K, Saxena S, Pollok R. Using corticosteroids appropriately in inflammatory bowel disease: A guide for primary care. Br. J. Gen. Pract. 2018; 68: 497-8.

107 Mañosa M, Cabré E, Garcia-Planella E, et al. Decision tree for early introduction of rescue therapy in active ulcerative colitis treated with steroids. Inflamm Bowel Dis 2011; 17: 2497-502.

108 Scott G, Roads N, Lewis W. P280 Reducing the overprescribing of oral corticosteroids in IBD using a steroid assessment tool. ECCO Congr. Abstr. 2018. https://www.eccoibd.eu/publications/congress-abstract-s/abstracts-2018/item/p280-reducing-theoverprescribing-of-oral-corticosteroids-in-ibd-using-a-steroid-assessment-tool.html (accessed Sept 24, 2019).

109 Chhaya V, Alexakis C, Saxena S, Pollok RC. The use of budesonide in Crohn's disease: A national population based study. Gut 2017; 66: A248.

110 Huscher D, Thiele K, Gromnica-Ihle E, et al. Dose-related patterns of glucocorticoidinduced side effects. Ann Rheum Dis 2009; 68: 1119-24.

111 Curtis JR, Westfall AO, Allison J, et al. Population-based assessment of adverse events associated with long-term glucocorticoid use. Arthritis Care Res. 2006; 55: 420-6.

112 McDougall R, Sibley J, Haga M, Russell A. Outcome in patients with rheumatoid arthritis receiving prednisone compared to matched controls. J Rheumatol 1994; 21: 1207-13.

113 Saag KG, Koehnke R, Caldwell JR, et al. Low dose long-term corticosteroid therapy in rheumatoid arthritis: An analysis of serious adverse events. Am J Med 1994; 96: 115-23.

114 Phulke S, Kaushik S, Kaur S, Pandav S. Steroid-induced Glaucoma: An Avoidable Irreversible Blindness. J Curr Glaucoma Pract 2017; 11: 67.

115 Panoulas VF, Douglas KMJ, Stavropoulos-Kalinoglou A, et al. Long-term exposure to 
medium-dose glucocorticoid therapy associates with hypertension in patients with rheumatoid arthritis. Rheumatology 2008; 47: 72-5.

116 Wolfe F, Michaud K. The risk of myocardial infarction and pharmacologic and nonpharmacologic myocardial infarction predictors in rheumatoid arthritis: A cohort and nested case-control analysis. Arthritis Rheum 2008; 58: 2612-21.

117 Sarlos P, Szemes K, Hegyi P, et al. Steroid but not Biological Therapy Elevates the risk of Venous Thromboembolic Events in Inflammatory Bowel Disease: A Meta-Analysis. J Crohns Colitis 2018; 12: 489-98.

118 Messer J, Reitman D, Sacks HS, Smith H, Chalmers TC. Association of Adrenocorticosteroid Therapy and Peptic-Ulcer Disease. N Engl J Med 1983; 309: 21-4.

119 Piper JM, Ray WA, Daugherty JR, Griffin MR. Corticosteroid use and peptic ulcer disease: Role of nonsteroidal anti-inflammatory drugs. Ann Intern Med 1991; 114: 735-40.

120 Canalis E, Mazziotti G, Giustina A, Bilezikian JP. Glucocorticoid-induced osteoporosis: Pathophysiology and therapy. Osteoporos. Int. 2007; 18: 1319-28.

121 Sugiyama T, Suzuki S, Yoshida T, et al. Age, initial dose and dose increase are independent risk factors for symptomatic vertebral fractures in glucocorticoid-treated male patients. Intern Med 2011; 50: 817-24.

122 Dilisio MF. Osteonecrosis following short-term, low-dose oral corticosteroids: A population-based study of 24 million patients. Orthopedics 2014; 37. DOI:10.3928/01477447-20140626-54.

123 Shigemura T, Nakamura J, Kishida S, et al. Incidence of osteonecrosis associated with corticosteroid therapy among different underlying diseases: prospective MRI study. Rheumatology (Oxford) 2011; 50: 2023-8.

124 Zizic TM, Marcoux C, Hungerford DS, Dansereau J V., Stevens MB. Corticosteroid therapy associated with ischemic necrosis of bone in systemic lupus erythematosus. Am J Med 1985; 79: 596-604.

125 Abeles M, Urman JD, Rothfield NF. Aseptic Necrosis of Bone in Systemic Lupus Erythematosus: Relationship to Corticosteroid Therapy. Arch Intern Med 1978; 138: 750-4.

126 Bolanos SH, Khan DA, Hanczyc M, Bauer MS, Dhanani N, Brown ES. Assessment of mood states in patients receiving long-term corticosteroid therapy and in controls with patientrated and clinician-rated scales. Ann Allergy, Asthma Immunol 2004; 92: 500-5.

127 Dubovsky AN, Arvikar S, Stern TA, Axelrod L. The Neuropsychiatric Complications of Glucocorticoid Use: Steroid Psychosis Revisited. Psychosomatics. 2012; 53: 103-15.

128 Da Silva JAP, Jacobs JWG, Kirwan JR, et al. Safety of low dose glucocorticoid treatment in rheumatoid arthritis: Published evidence and prospective trial data. Ann. Rheum. Dis. 2006; 65: 285-93. 
129 Cooper MS, Stewart PM. Corticosteroid insufficiency in acutely ill patients. N. Engl. J. Med. 2003; 348: 727-34.

130 Axelrod L. Perioperative management of patients treated with glucocorticoids. Endocrinol Metab Clin North Am 2003; 32: 367-83.

131 LaRochelle GE, LaRochelle AG, Ratner RE, Borenstein DG. Recovery of the hypothalamicpituitary-adrenal (HPA) axis in patients with rheumatic diseases receiving low-dose prednisone. Am J Med 1993; 95: 258-64.

132 Gurwitz JH. Glucocorticoids and the Risk for Initiation of Hypoglycemic Therapy. Arch Intern Med 1994; 154: 97.

133 Sandborn WJ, Hanauer SB, Rutgeerts P, et al. Adalimumab for maintenance treatment of Crohn's disease: Results of the CLASSIC II trial. Gut 2007; 56: 1232-9.

134 Colombel JF, Sandborn WJ, Rutgeerts P, et al. Adalimumab for Maintenance of Clinical Response and Remission in Patients With Crohn's Disease: The CHARM Trial. Gastroenterology 2007; 132: 52-65.

135 Sandborn WJ, Feagan BG, Rutgeerts P, et al. Vedolizumab as induction and maintenance therapy for Crohn's disease. N Engl J Med 2013; 369: 711-21.

136 Feagan BG, Sandborn WJ, Gasink C, et al. Ustekinumab as induction and maintenance therapy for Crohn's disease. N Engl J Med 2016; 375: 1946-60.

137 Rutgeerts P, Sandborn WJ, Feagan BG, et al. Infliximab for induction and maintenance therapy for ulcerative colitis. $N$ Engl J Med 2005; 353: 2462-76.

138 Sandborn, W, van Assche G, Reinisch W et al. Adalimumab in the Treatment of Moderateto-Severe Ulcerative Colitis: ULTRA 2 Trial Results. Gastroenterol Hepatol (N Y) 2013; 9: 317-20.

139 Sandborn WJ, Feagan BG, Marano C, et al. Subcutaneous golimumab maintains clinical response in patients with moderate-to-severe ulcerative colitis. Gastroenterology 2014; 146. DOI:10.1053/j.gastro.2013.06.010.

140 Feagan BG, Rutgeerts P, Sands BE, et al. Vedolizumab as induction and maintenance therapy for ulcerative colitis. $N$ Engl J Med 2013; 369: 699-710.

141 Sandborn WJ, Su C, Sands BE, et al. Tofacitinib as induction and maintenance therapy for ulcerative colitis. $N$ Engl J Med 2017; 376: 1723-36.

142 Feagan BG, Fedorak RN, Irvine EJ, et al. A comparison of methotrexate with placebo for the maintenance of remission in Crohn's disease. North American Crohn's Study Group Investigators. N Engl J Med 2000; 342: 1627-32.

143 Chande N, Townsend CM, Parker CE, MacDonald JK. Azathioprine or 6-mercaptopurine for induction of remission in Crohn's disease. Cochrane database Syst Rev 2016; 10: CD000545.

144 Colombel JF, Sandborn WJ, Reinisch W, et al. Infliximab, azathioprine, or combination 
therapy for Crohn's disease. N Engl J Med 2010; 362: 1383-95.

145 Ardizzone S, Maconi G, Russo A, Imbesi V, Colombo E, Porro GB. Randomised controlled trial of azathioprine and 5-aminosalicylic acid for treatment of steroid dependent ulcerative colitis. Gut 2006; 55: 47-53.

146 Armuzzi A, Pugliese D, Danese S, et al. Infliximab in steroid-dependent ulcerative colitis: effectiveness and predictors of clinical and endoscopic remission. Inflamm Bowel Dis 2013; 19: 1065-72.

147 Sands BE, Peyrin-Biroulet L, Loftus E V, et al. Vedolizumab versus Adalimumab for Moderate-to-Severe Ulcerative Colitis. N Engl J Med 2019; 381: 1215-26.

148 Sands BE, Sandborn WJ, Panaccione R, et al. Ustekinumab as Induction and Maintenance Therapy for Ulcerative Colitis. N Engl J Med 2019; 381: 1201-14. 
Manuscript Doi: 10.1093/ecco-jcc/jjaa053

TABLES

Table 1: Pharmacologic comparison of commonly used systemic glucocorticoids. ${ }^{3}$

\begin{tabular}{|c|c|c|c|c|}
\hline & $\begin{array}{l}\text { Equivalent dose } \\
\text { (mg) }\end{array}$ & $\begin{array}{l}\text { Glucocorticoid activity } \\
\text { relative to hydrocortisone }\end{array}$ & $\begin{array}{l}\text { Mineralocorticoid activity } \\
\text { relative to hydrocortisone }\end{array}$ & $\begin{array}{l}\text { Duration of } \\
\text { action (hours) }\end{array}$ \\
\hline \multicolumn{5}{|l|}{ Short acting } \\
\hline Hydrocortisone & 20 & 1 & 1 & $8-12$ \\
\hline Cortisone acetate & 25 & 0.8 & 0.8 & $8-12$ \\
\hline \multicolumn{5}{|l|}{ Intermediate acting } \\
\hline Prednisone & 5 & 4 & 0.8 & $12-36$ \\
\hline Prednisolone & 5 & 4 & 0.8 & $12-36$ \\
\hline Methylprednisolone & 4 & 5 & 0.5 & $12-36$ \\
\hline Triamcinolone & 4 & 5 & 0 & $12-36$ \\
\hline \multicolumn{5}{|l|}{ Long acting } \\
\hline Dexamethasone & 0.75 & 30 & 0 & $36-72$ \\
\hline Betamethasone & 0.6 & 30 & 0 & $36-72$ \\
\hline \multicolumn{5}{|l|}{ Mineralocorticoids } \\
\hline Fludrocortisone & - & $10-15$ & $125-150$ & $12-36$ \\
\hline
\end{tabular}


Table 2: Adverse effects of first-generation corticosteroids with reported frequencies based on published evidence.

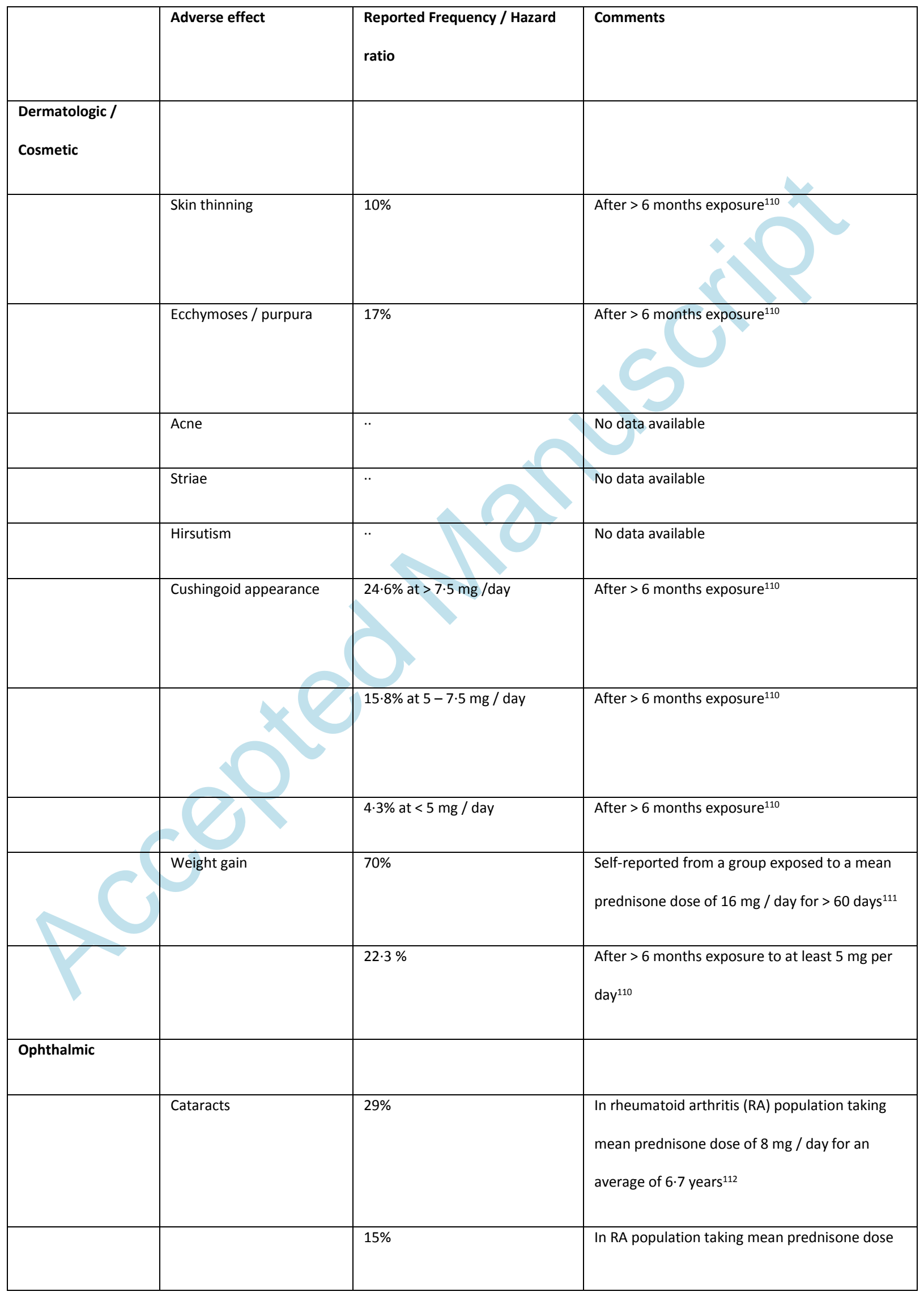


Manuscript Doi: 10.1093/ecco-jcc/jjaa053

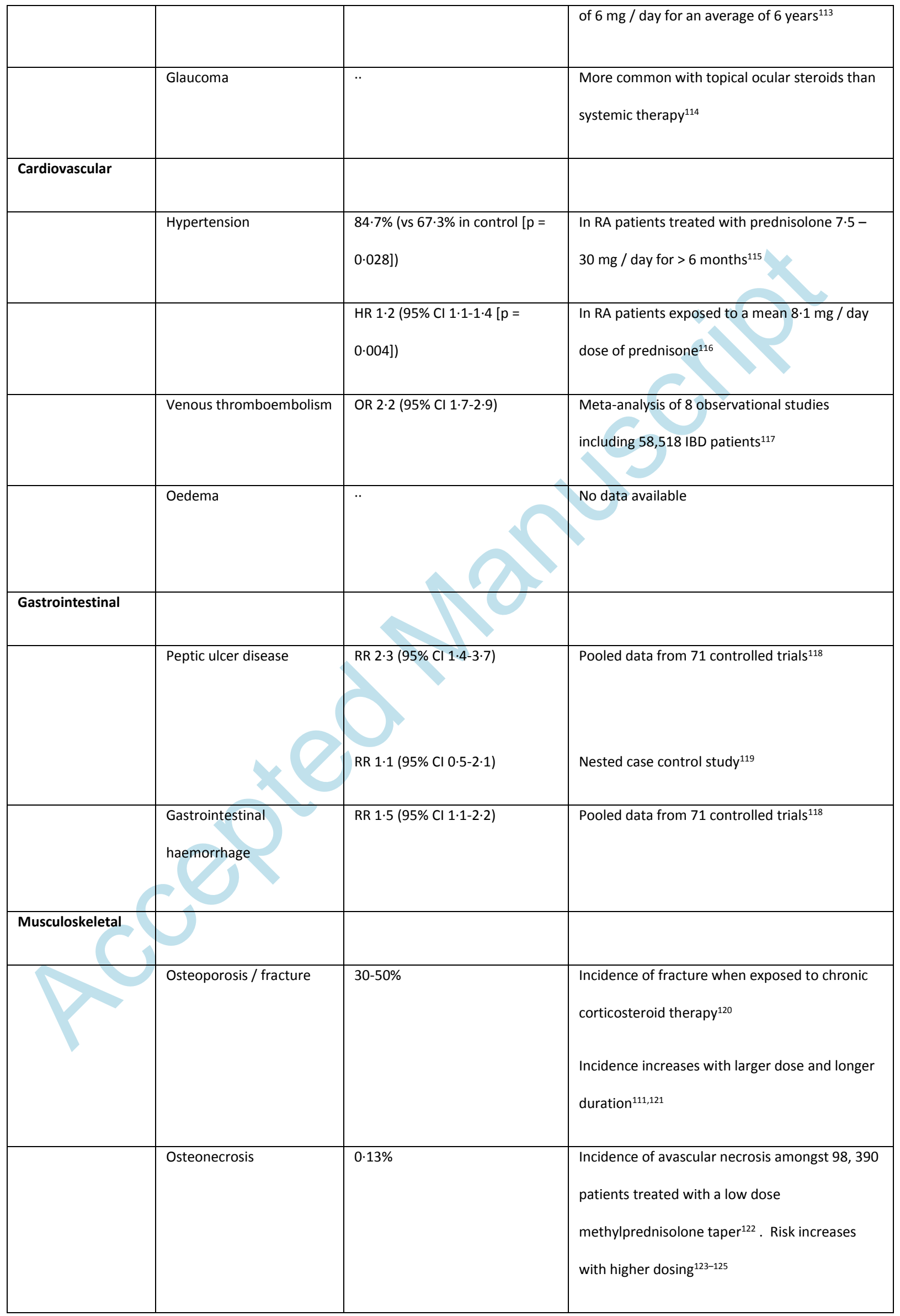


Manuscript Doi: 10.1093/ecco-jcc/jjaa053

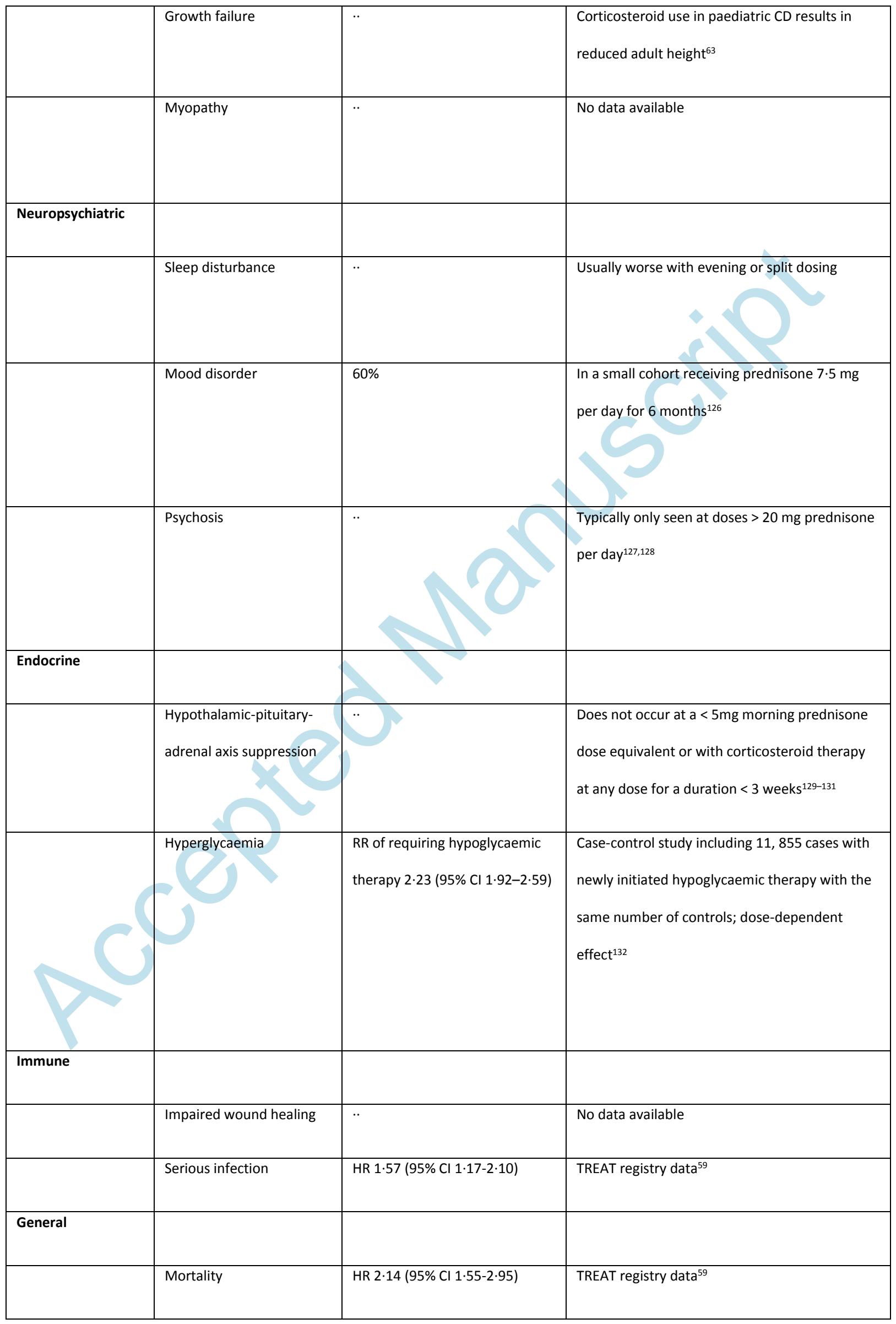


Manuscript Doi: 10.1093/ecco-jcc/jjaa053

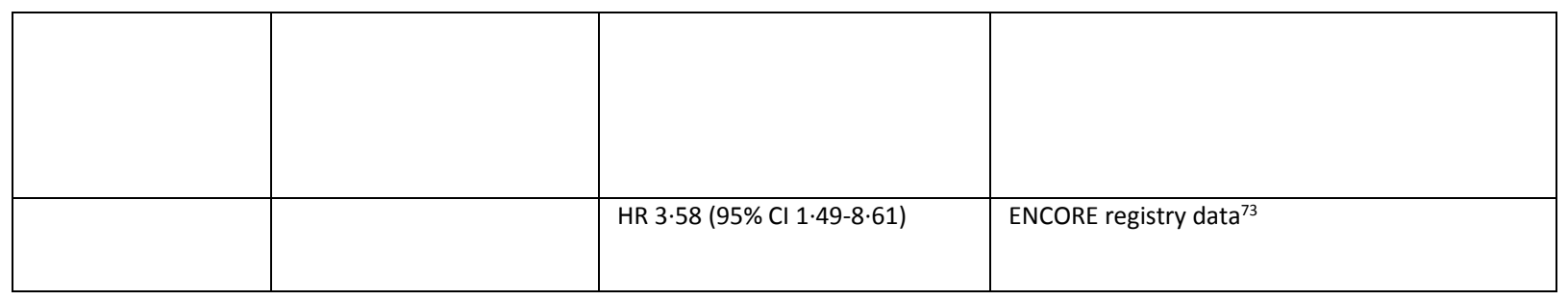


Table 3: Corticosteroid dose and tapering regimens from major randomised control trials in moderate-severe Crohn's disease. ${ }^{92}$

\begin{tabular}{|c|c|c|c|c|c|c|}
\hline & $\begin{array}{l}\text { Patient numbers } \\
\text { (placebo [P] and } \\
\text { intervention [I] } \\
\text { arms) }\end{array}$ & $\begin{array}{l}\text { Concomitant } \\
\text { corticosteroid } \\
\text { at trial entry } \\
\text { (\%) }\end{array}$ & $\begin{array}{l}\text { Maximum } \\
\text { prednisone } \\
\text { equivalent } \\
\text { dose at trial } \\
\text { entry }\end{array}$ & $\begin{array}{l}\text { Taper } \\
\text { initiation }\end{array}$ & $\begin{array}{l}\text { Anticipated } \\
\text { taper } \\
\text { completion* }\end{array}$ & Taper schedule \\
\hline $\begin{array}{l}\text { CLASSIC-II } \\
\text { (maintenance } \\
\text { phase) }^{133}\end{array}$ & $\begin{array}{l}\text { P: } 18 \\
\text { I: } 37 \text { (Adalimumab) }\end{array}$ & $\begin{array}{l}\text { P: } 56 \\
\text { I: } 46\end{array}$ & $30 \mathrm{mg} / \mathrm{day}$ & Week 8 & Week 16 & $\begin{array}{l}\text { Reduce by } 5 \mathrm{mg} / \text { week } \\
\text { until } 10 \mathrm{mg} / \text { day then } \\
2.5 \mathrm{mg} / \text { week }\end{array}$ \\
\hline CHARM $^{134}$ & $\begin{array}{l}\text { P: } 170 \\
\text { I: } 329 \text { (Adalimumab) }\end{array}$ & $P+I: 42$ & $30 \mathrm{mg} / \mathrm{day}$ & Week 8 & Week 16 & $\begin{array}{l}\text { Reduce by } 5 \mathrm{mg} / \text { week } \\
\text { until } 10 \mathrm{mg} / \text { day then } \\
2.5 \mathrm{mg} / \text { week }\end{array}$ \\
\hline GEMINI II ${ }^{135}$ & $\begin{array}{l}\text { P: } 153 \\
\text { I: } 308 \text { (Vedolizumab) }\end{array}$ & $\begin{array}{l}P: 54 \\
\text { I: } 53\end{array}$ & $30 \mathrm{mg} / \mathrm{day}$ & Week 6 & Week 14 & $\begin{array}{l}\text { Reduce by } 5 \mathrm{mg} / \text { week } \\
\text { until } 10 \mathrm{mg} / \text { day then } \\
2.5 \mathrm{mg} / \text { week }\end{array}$ \\
\hline IM-UNITI $^{136}$ & $\begin{array}{l}\text { P: } 131 \\
\text { I: } 257 \\
\text { (Ustekinumab) }\end{array}$ & $P: 44$ & 40mg/day & Week 8 & Week 18 & $\begin{array}{l}\text { Reduce by } 5 \mathrm{mg} / \text { week } \\
\text { until } 10 \mathrm{mg} / \text { day then } \\
2.5 \mathrm{mg} / \text { week }\end{array}$ \\
\hline
\end{tabular}

* A uniform corticosteroid taper was not enforced. In the event of clinical worsening, investigators were permitted to increase the dose back up to the corticosteroid dose at trial entry and then resume taper within 2-4 weeks. 
Table 4: Corticosteroid dose and tapering regimens from major randomised controlled trials in moderate-severe ulcerative colitis. ${ }^{92}$

\begin{tabular}{|c|c|c|c|c|c|c|}
\hline & $\begin{array}{l}\text { Patient } \\
\text { numbers } \\
\text { (placebo }[\mathrm{P}] \text { and } \\
\text { intervention }[\mathrm{I}] \\
\text { arms) }\end{array}$ & $\begin{array}{l}\text { Concomitant } \\
\text { corticosteroid } \\
\text { at trial entry (\%) }\end{array}$ & $\begin{array}{l}\text { Maximum } \\
\text { prednisone } \\
\text { equivalent } \\
\text { dose at trial } \\
\text { entry }\end{array}$ & $\begin{array}{l}\text { Taper } \\
\text { initiation }\end{array}$ & $\begin{array}{l}\text { Anticipated } \\
\text { taper } \\
\text { completion* }\end{array}$ & Taper schedule \\
\hline ACT $1^{137}$ & $\begin{array}{l}\text { P: } 121 \\
\text { I: } 121 \\
\text { (Infliximab) }\end{array}$ & $\begin{array}{l}\text { P: } 65 \\
\text { I: } 58\end{array}$ & $40 \mathrm{mg} /$ day & Week 8 & Week 20 & $\begin{array}{l}\text { Reduce by } 5 \mathrm{mg} / \text { week until } \\
20 \mathrm{mg} / \text { day then } 2.5 \mathrm{mg} / \text { week }\end{array}$ \\
\hline ACT $2^{137}$ & $\begin{array}{l}\text { P: } 123 \\
\text { I: } 121 \\
\text { (Infliximab) }\end{array}$ & $\begin{array}{l}\mathrm{P}: 49 \\
\text { I: } 50\end{array}$ & $40 \mathrm{mg} /$ day & Week 8 & Week 20 & $\begin{array}{l}\text { Reduce by } 5 \mathrm{mg} / \text { week until } \\
20 \mathrm{mg} / \text { day then } 2.5 \mathrm{mg} / \text { week }\end{array}$ \\
\hline${\text { ULTRA } 2^{138}}^{138}$ & $\begin{array}{l}\text { P: } 246 \\
\text { I: } 248 \\
\text { (Adalimumab) }\end{array}$ & $\begin{array}{l}\text { P: } 75 \\
\text { I: } 81\end{array}$ & $20 \mathrm{mg} /$ day & Week 8 & Week 14 & $\begin{array}{l}\text { Reduce by } 5 \mathrm{mg} / \text { week until } \\
10 \mathrm{mg} / \text { day then } 2.5 \mathrm{mg} / \text { week }\end{array}$ \\
\hline PURSUIT-M ${ }^{139}$ & $\begin{array}{l}\text { P: } 156 \\
\text { I: } 154\end{array}$ & $\begin{array}{l}P: 53 \\
I: 51\end{array}$ & $40 \mathrm{mg} /$ day & Week 6 & Week 18 & $\begin{array}{l}\text { Reduce by } 5 \mathrm{mg} / \text { week until } \\
20 \mathrm{mg} / \text { day then } 2.5 \mathrm{mg} / \text { week }\end{array}$ \\
\hline GEMINI I I & $\begin{array}{l}\text { P: } 149 \\
\text { I: } 257 \\
\text { (Vedolizumab) }\end{array}$ & $\begin{array}{l}P: 56 \\
\text { I: } 53\end{array}$ & $30 \mathrm{mg} /$ day & Week 6 & Week 14 & $\begin{array}{l}\text { Reduce by } 5 \mathrm{mg} / \text { week until } \\
10 \mathrm{mg} / \text { day then } 2.5 \mathrm{mg} / \text { week }\end{array}$ \\
\hline $\begin{array}{l}\text { OCTAVE- } \\
\text { Sustain }^{141}\end{array}$ & $\begin{array}{l}\text { P: } 198 \\
\text { I: } 395 \\
\text { (Tofacitinib) }\end{array}$ & $\begin{array}{l}\text { P: } 51 \\
\text { I: } 51\end{array}$ & $25 \mathrm{mg} /$ day & Week 5 & Week 14 & $\begin{array}{l}\text { Reduce by } 5 \mathrm{mg} / \text { week until } \\
20 \mathrm{mg} / \text { day then } 2.5 \mathrm{mg} / \text { week }\end{array}$ \\
\hline
\end{tabular}

* A uniform corticosteroid taper was not enforced. In the event of clinical worsening, investigators were permitted to increase the dose back up to the corticosteroid dose at trial entry and then resume taper within 2-4 weeks. 
Table 5: Summary of trial data publishing corticosteroid-free remission data for different maintenance treatments in Crohn's disease

\begin{tabular}{|c|c|c|c|c|c|c|c|}
\hline $\begin{array}{l}\text { Author / } \\
\text { Trial } \\
\text { name }\end{array}$ & Year & Drug & Trial design & Patient numbers & $\begin{array}{l}\text { Time } \\
\text { point of } \\
\text { analysis }\end{array}$ & $\begin{array}{l}\text { Corticosteroid- } \\
\text { free clinical } \\
\text { remission }\end{array}$ & $\begin{array}{l}\text { P value / } \\
\text { Relative risk }\end{array}$ \\
\hline $\begin{array}{l}\text { Feagan et } \\
\text { al }^{142}\end{array}$ & 2000 & $\begin{array}{l}\text { Methotrexate } \\
\text { (intramuscular) } \\
15 \text { mg weekly }\end{array}$ & RCT & $\begin{array}{l}\text { Total: } 76 \\
\text { Methotrexate: } 40 \\
\text { Placebo: } 36\end{array}$ & 40 weeks & $\begin{array}{l}\text { Methotrexate: } \\
72 \% \\
\text { Placebo: } 42 \%\end{array}$ & $P=0.01$ \\
\hline $\begin{array}{l}\text { Chande et } \\
\text { al }^{143}\end{array}$ & 2016 & Azathioprine & $\begin{array}{l}\text { Cochrane } \\
\text { systematic } \\
\text { review of } \\
\text { RCTs }\end{array}$ & $\begin{array}{l}\text { Total: } 233 \\
\text { Azathioprine: } 163 \\
\text { Placebo: } 70\end{array}$ & & $\begin{array}{l}\text { Azathioprine: } 64 \% \\
\text { Placebo: } 46 \% \\
\text { (defined as } \\
\text { prednisolone } \\
\text { dose < 10mg per } \\
\text { day) }\end{array}$ & $\begin{array}{l}\text { RR: } 1.34 \\
(95 \% \mathrm{Cl} 1.02- \\
1.77)\end{array}$ \\
\hline SONIC $^{144}$ & 2010 & $\begin{array}{l}\text { Arm 1: } \\
\text { Azathioprine } \\
\text { Arm 2: Infliximab } \\
\text { Arm 3: } \\
\text { Azathioprine + } \\
\text { infliximab }\end{array}$ & RCT & $\begin{array}{l}\text { Total: } 508 \\
\text { Arm 1: } 170 \\
\text { Arm 2: } 169 \\
\text { Arm 3: } 169\end{array}$ & 26 weeks & $\begin{array}{l}\text { Azathioprine: } 30 \% \\
\text { Infliximab: } 44.4 \% \\
\text { Azathioprine + } \\
\text { infliximab: } 56.8 \%\end{array}$ & $\begin{array}{l}\mathrm{P}<0.001 \text { for } \\
\text { combination } \\
\text { therapy vs } \\
\text { azathioprine } \\
P=0.006 \text { for } \\
\text { infliximab vs } \\
\text { azathioprine } \\
P=0.02 \text { for } \\
\text { combination } \\
\text { therapy vs } \\
\text { infliximab }\end{array}$ \\
\hline CHARM $^{134}$ & 2007 & Adalimumab & RCT & $\begin{array}{l}\text { Total: } 778 \\
\text { Adalimumab } 40 \mathrm{mg} \\
\text { second weekly: } 260 \\
\text { Adalimumab } 40 \mathrm{mg} \\
\text { weekly: } 257\end{array}$ & 26 weeks & $\begin{array}{l}\text { Adalimumab } \\
\text { second weekly: } \\
35 \% \\
\text { Adalimumab } \\
\text { weekly: } 30 \%\end{array}$ & $\begin{array}{l}\mathrm{P}<0.001 \text { for } \\
\text { both } \\
\text { adalimumab } \\
\text { doses vs } \\
\text { placebo }\end{array}$ \\
\hline
\end{tabular}


Manuscript Doi: 10.1093/ecco-jcc/jjaa053

\begin{tabular}{|c|c|c|c|c|c|c|c|}
\hline & & & & Placebo: 261 & & Placebo: 3\% & \\
\hline $\begin{array}{l}\text { GEMINI } \\
\text { II }^{135}\end{array}$ & 2013 & Vedolizumab & RCT & $\begin{array}{l}\text { Total: } 461 \\
\text { Vedolizumab } 8 \text { weekly: } \\
154 \\
\text { Vedolizumab } 4 \text { weekly: } \\
154 \\
\text { Placebo: } 153\end{array}$ & 52 weeks & $\begin{array}{l}\text { Vedolizumab } 8 \\
\text { weekly: } 31.7 \% \\
\text { Vedolizumab } 4 \\
\text { weekly: } 28.8 \% \\
\text { Placebo: } 15.9 \%\end{array}$ & $\begin{array}{l}\mathrm{P}=0.02 \text { for } 8 \\
\text { weekly vs } \\
\text { placebo } \\
\mathrm{P}=0.04 \text { for } 4 \\
\text { weekly vs } \\
\text { placebo }\end{array}$ \\
\hline $\begin{array}{l}\text { IM- } \\
\text { UNITI'136 }\end{array}$ & 2016 & Ustekinumab & RCT & $\begin{array}{l}\text { Total: } 388 \\
\text { Ustekinumab } 8 \text { weekly: } \\
128 \\
\text { Ustekinumab } 12 \\
\text { weekly: } 129 \\
\text { Placebo: } 131\end{array}$ & 44 weeks & $\begin{array}{l}\text { Ustekinumab } 8 \\
\text { weekly: } 46.9 \% \\
\text { Ustekinumab } 12 \\
\text { weekly: } 42.6 \% \\
\text { Placebo: } 29.8 \%\end{array}$ & $\begin{array}{l}\mathrm{P}=0.004 \text { for } 8 \\
\text { weekly } \\
\text { ustekinumab } \\
\text { vs placebo } \\
\mathrm{P}=0.04 \text { for } 12 \\
\text { weekly } \\
\text { ustekinumab } \\
\text { vs placebo }\end{array}$ \\
\hline
\end{tabular}


Table 6: Summary of trial data publishing corticosteroid-free remission data for different maintenance treatments in ulcerative colitis

\begin{tabular}{|c|c|c|c|c|c|c|c|}
\hline $\begin{array}{l}\text { Author / Trial } \\
\text { name }\end{array}$ & Year & Drug & Trial design & Patient numbers & $\begin{array}{l}\text { Time } \\
\text { point of } \\
\text { analysis }\end{array}$ & $\begin{array}{l}\text { Corticosteroid-free } \\
\text { clinical remission }\end{array}$ & $\begin{array}{l}\text { P value / } \\
\text { Odds ratio }\end{array}$ \\
\hline $\begin{array}{l}\text { Ardizzone et } \\
\text { al }^{145}\end{array}$ & 2006 & Azathioprine & RCT & $\begin{array}{l}\text { Total: } 72 \\
\text { Azathioprine } 2 \\
\mathrm{mg} / \mathrm{kg} / \text { day: } 36 \\
\text { Oral 5-ASA } 3.2 \mathrm{~g} / \text { day: } \\
36\end{array}$ & 26 weeks & $\begin{array}{l}\text { Azathioprine: } 53 \% \\
\text { Oral 5-ASA: } 21 \% \\
\text { (combined clinical } \\
\text { and endoscopic } \\
\text { remission) }\end{array}$ & $\begin{array}{l}\text { OR } 4.78 \\
(95 \% \mathrm{Cl} 1.57 \\
-14.5)\end{array}$ \\
\hline ACT $2^{137}$ & 2005 & Infliximab & RCT & $\begin{array}{l}\text { Total: } 364 \\
\text { Infliximab } 5 \mathrm{mg} / \mathrm{kg} \text { : } 121 \\
\text { Infliximab } 10 \mathrm{mg} / \mathrm{kg} \text { : } \\
120\end{array}$ & 30 weeks & $\begin{array}{l}\text { Infliximab } 5 \mathrm{mg} / \mathrm{kg} \text { : } \\
18.3 \% \\
\text { Infliximab } 10 \mathrm{mg} / \mathrm{kg} \text { : } \\
27.3 \% \\
\text { Placebo: } 3.3 \%\end{array}$ & $\begin{array}{l}P=0.01 \text { for } \\
5 \mathrm{mg} / \mathrm{kg} \\
P<0.001 \text { for } \\
10 \mathrm{mg} / \mathrm{kg}\end{array}$ \\
\hline Armuzzi et al ${ }^{146}$ & 2013 & Infliximab & $\begin{array}{l}\text { Cohort } \\
\text { study }\end{array}$ & $\begin{array}{l}126 \text { steroid-dependent } \\
\text { UC patients }\end{array}$ & 52 weeks & $\begin{array}{l}\text { Steroid-free clinical } \\
\text { remission: } 47 \% \\
\text { Steroid-free } \\
\text { endoscopic remission: } \\
33 \%\end{array}$ & - \\
\hline ULTRA $2^{138}$ & 2013 & Adalimumab & RCT & $\begin{array}{l}\text { Total: } 494 \\
\text { Adalimumab: } 248 \\
\text { Placebo: } 246\end{array}$ & 52 weeks & $\begin{array}{l}\text { Adalimumab: } 13.3 \% \\
\text { Placebo: } 5.7 \%\end{array}$ & $P=0.035$ \\
\hline $\begin{array}{l}\text { PURSUIT- } \\
\text { Maintenance }^{139}\end{array}$ & 2014 & Golimumab & RCT & $\begin{array}{l}\text { Total: } 464 \\
\text { Golimumab } 50 \mathrm{mg}: 154 \\
\text { Golimumab 100mg: } 154 \\
\text { Placebo: } 156\end{array}$ & 52 weeks & $\begin{array}{l}\text { Golimumab } 50 \mathrm{mg} \text { : } \\
28.2 \% \\
\text { Golimumab } 100 \mathrm{mg} \text { : } \\
23.2 \%\end{array}$ & $\begin{array}{l}P=0.279 \text { for } \\
50 \mathrm{mg} \text { vs } \\
\text { placebo } \\
P=0.423 \text { for } \\
100 \mathrm{mg} \text { vs }\end{array}$ \\
\hline
\end{tabular}


Manuscript Doi: 10.1093/ecco-jcc/jjaa053

\begin{tabular}{|c|c|c|c|c|c|c|c|}
\hline & & & & & & Placebo: $18.4 \%$ & placebo \\
\hline GEMINI I I & 2013 & Vedolizumab & RCT & $\begin{array}{l}\text { Vedolizumab } 4 \text { weekly: } \\
125 \\
\text { Vedolizumab } 8 \text { weekly: } \\
122 \\
\text { Placebo: } 126\end{array}$ & 52 weeks & $\begin{array}{l}\text { Vedolizumab } 4 \\
\text { weekly: } 45.2 \% \\
\text { Vedolizumab } 8 \\
\text { weekly: } 31.4 \% \\
\text { Placebo: } 13.9 \%\end{array}$ & $\begin{array}{l}P<0.001 \text { for } \\
4 \text { weekly vs } \\
\text { placebo } \\
P=0.01 \text { for } \\
8 \text { weekly vs } \\
\text { placebo }\end{array}$ \\
\hline VARSITY $^{147}$ & 2019 & $\begin{array}{l}\text { Adalimumab } \\
\text { vs } \\
\text { Vedolizumab }\end{array}$ & RCT & $\begin{array}{l}\text { Total: } 769 \\
\text { Adalimumab: } \\
\text { Vedolizumab: }\end{array}$ & 52 weeks & $\begin{array}{l}\text { Adalimumab: } 21.8 \% \\
\text { Vedolizumab: } 12.6 \%\end{array}$ & $\begin{array}{l}-9.3 \% \\
\text { difference } \\
(95 \% \mathrm{Cl}- \\
18.9-0.4)\end{array}$ \\
\hline $\begin{array}{l}\text { OCTAVE } \\
\text { Sustain }^{141}\end{array}$ & 2017 & Tofacitinib & RCT & $\begin{array}{l}\text { Total: } 593 \\
\text { Tofacitinib } 5 \mathrm{mg} \text { twice } \\
\text { daily: } 198 \\
\text { Tofacitinib } 10 \mathrm{mg} \text { twice } \\
\text { daily: } 197 \\
\text { Placebo: } 198\end{array}$ & 52 weeks & $\begin{array}{l}\text { Tofacitinib } 5 \mathrm{mg} \text { twice } \\
\text { daily: } 35.4 \% \\
\text { Tofacitinib } 10 \mathrm{mg} \\
\text { twice daily: } 47.3 \% \\
\text { Placebo: } 5.1 \%\end{array}$ & $\begin{array}{l}\mathrm{P}<0.001 \text { for } \\
\text { both doses }\end{array}$ \\
\hline UNIFI $^{148}$ & 2019 & Ustekinumab & RCT & $\begin{array}{l}\text { Total: } 523 \\
\text { Ustekinumab } 8 \text { weekly: } \\
176 \\
\text { Ustekinumab } 12 \\
\text { weekly: } 172 \\
\text { Placebo: } 175\end{array}$ & 44 weeks & $\begin{array}{l}\text { Ustekinumab } 8 \\
\text { weekly: } 42.0 \% \\
\text { Ustekinumab } 12 \\
\text { weekly: } 37.8 \% \\
\text { Placebo: } 23.4 \%\end{array}$ & $\begin{array}{l}P<0.001 \text { for } \\
8 \text { weekly vs } \\
\text { placebo } \\
P=0.002 \text { for } \\
12 \text { weekly vs } \\
\text { placebo }\end{array}$ \\
\hline
\end{tabular}

